\title{
Review \\ The Roles of Post-Translational Modifications on mTOR Signaling
}

\author{
Shasha Yin, Liu Liu and Wenjian Gan *
}

Citation: Yin, S.; Liu, L.; Gan, W. The Roles of Post-Translational Modifications on mTOR Signaling. Int. J. Mol. Sci. 2021, 22, 1784. https://doi.org/10.3390/ijms22041 784

Academic Editor: Elena

A. Goncharova

Received: 5 January 2021

Accepted: 8 February 2021

Published: 11 February 2021

Publisher's Note: MDPI stays neutral with regard to jurisdictional claims in published maps and institutional affiliations.

Copyright: (C) 2021 by the authors Licensee MDPI, Basel, Switzerland. This article is an open access article distributed under the terms and conditions of the Creative Commons Attribution (CC BY) license (https:// creativecommons.org/licenses/by/ $4.0 /)$.
Department of Biochemistry and Molecular Biology, Medical University of South Carolina, Charleston, SC 29425, USA; yin@musc.edu (S.Y.); lliu@musc.edu (L.L.)

* Correspondence: ganw@musc.edu; Tel.: +1-843-792-8402

\begin{abstract}
The mechanistic target of rapamycin (mTOR) is a master regulator of cell growth, proliferation, and metabolism by integrating various environmental inputs including growth factors, nutrients, and energy, among others. mTOR signaling has been demonstrated to control almost all fundamental cellular processes, such as nucleotide, protein and lipid synthesis, autophagy, and apoptosis. Over the past fifteen years, mapping the network of the mTOR pathway has dramatically advanced our understanding of its upstream and downstream signaling. Dysregulation of the mTOR pathway is frequently associated with a variety of human diseases, such as cancers, metabolic diseases, and cardiovascular and neurodegenerative disorders. Besides genetic alterations, aberrancies in post-translational modifications (PTMs) of the mTOR components are the major causes of the aberrant mTOR signaling in a number of pathologies. In this review, we summarize current understanding of PTMs-mediated regulation of mTOR signaling, and also update the progress on targeting the mTOR pathway and PTM-related enzymes for treatment of human diseases.
\end{abstract}

Keywords: mTOR; post-translational modifications; inhibitors; human diseases

\section{Introduction}

The mechanistic target of the rapamycin (mTOR) pathway is a central sensor of environmental clues, such as growth factors, nutrients, and energy, through which it controls proper cell growth and metabolism. Imbalances in the mTOR pathway including full inhibition or constitutive activation may disrupt the cellular homeostasis, leading to human diseases including but not limited to cancers, metabolic diseases, and aging and neurodegenerative disorders [1-3]. In the past three decades, studies have been exponentially expanded to map the landscape of the mTOR pathway, providing insightful knowledge for targeting this fundamental pathway to treat human diseases, particularly cancers.

mTOR is an evolutionarily conversed protein kinase from yeast to human. In mammals, mTOR is the catalytic subunit of two different complexes (Figure 1), termed mTOR complex 1 (mTORC1) and mTOR complex 2 (mTORC2). These two complexes share two common subunits: mTOR and mLST8 (also known as G $\beta L$ ). The core component of mTORC1 includes Raptor, while mTORC2 contains Rictor and Sin1 (also known as MIP1 for MEKK2 interacting protein 1) [4-7]. Among these components, mLST8 is required for stabilization of the mTOR kinase domain [8]. Raptor is essential for mTORC1 cellular localization and substrate recruitment, as well as conferring mTORC1 rapamycinsensitivity $[9,10]$. Sin1 is indispensable for the maintenance of mTORC2 integrity and substrates binding [11] and Rictor defines mTORC1 rapamycin insensitivity [7]. In addition, DEPTOR (DEP domain-containing mTOR-interacting protein) binds both mTORC1 and mTORC2 and functions as an endogenous inhibitor of both complexes [12]. 


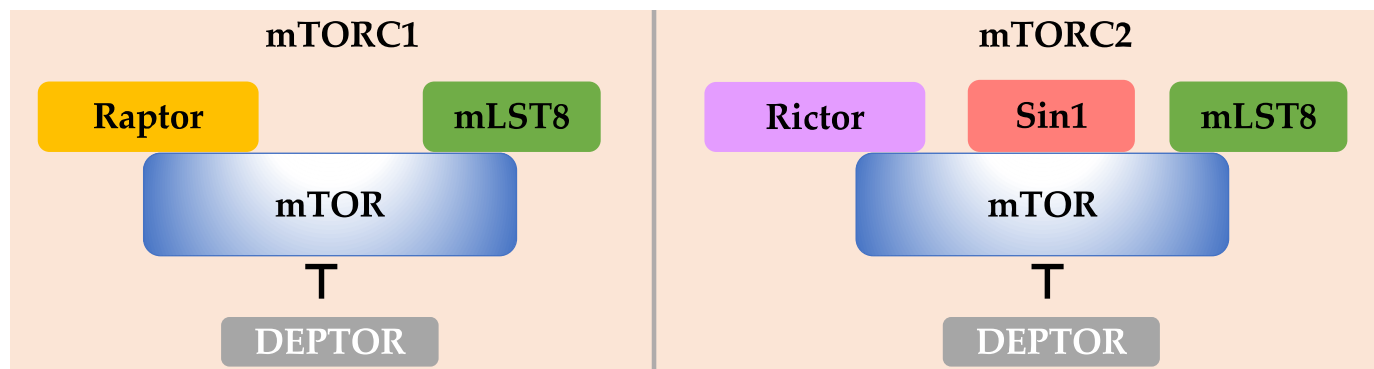

Figure 1. Core components of mTORC1 and mTORC2 complexes. mTOR and mLST8 are two shared subunits. Raptor defines the mTORC1 complex, while Rictor and Sin1 define mTORC2. DEPTOR is an endogenous inhibitor of both mTORC1 and mTORC2 complexes.

mTORC1 exerts its biological functions by phosphorylating a large number of downstream proteins. mTORC1 phosphorylates S6K and 4E-BP1 to promote protein synthesis [13]. mTORC1 also promotes lipid synthesis by promoting Lipin 1 phosphorylation and consequent activation of the transcriptional programs driven by SREBP1/2 and PPAR $\gamma$ [14]. Moreover, $\mathrm{mTORC} 1$ was reported to stimulate de novo synthesis of purine and pyrimidine through ATF4/MTHFD2 and S6K1/CAD, respectively [15-17]. Furthermore, mTORC1 suppresses autophagy by directly phosphorylating ULK1, ATG13, UVRAG, and TFEB [18]. mTORC1 activation is spatially and temporally controlled by upstream inputs, notably amino acids and growth factors. In response to amino acids stimulation, Rag GTPases (Rags) are recruited to the lysosome by the Ragulator complex (p18, p14, MP1, C7orf59, and HBXIP) $[19,20]$. Subsequently, Ragulator functions as a guanine nucleotide exchange factor (GEF) to load GTP on RagA/B and the FLCN/FNIP complex acts as a GTPase-activating protein (GAP) to load GDP on RagC/D, promoting formation of the heterodimer consisting of GTP-loaded RagA/B and GDP-loaded RagC/D [19,21]. Activated Rags directly interact with Raptor to recruit mTORC1 to lysosome [22], where it binds to Rheb GTPase for maximal activation $[23,24]$. Unlike Rags, Rheb activity is primarily controlled by growth factors through the Akt/TSC signaling axis [25-28]. In addition to the abovementioned regulators, many proteins have also been identified to mediate the amino acids-induced activation of mTORC1 in the past fifteen years, including the GATOR1 complex (a GAP for RagA/B [29]), GATOR2 complex (an inhibitor of GATOR1 with unknown function [29]), KICSTOR complex (a mediator of GATOR1 lysosomal localization [30,31]), Sestrin2 (leucine sensor [32,33]), SAMTOR (S-adenosylmethionine sensor [34]), and SLC38A9 and CASTOR1 (arginine sensors [35,36]). Collectively, these components form a sophisticated network centering on the Rags and Rheb GTPases to regulate mTORC1 activation in response to amino acids and growth factors (Figure 2).

Unlike mTORC1, mTORC2 is insensitive to rapamycin and has distinct roles on metabolism, cytoskeleton regulation, cell proliferation, and survival $[7,11,37]$. These biological functions of mTORC2 are achieved by phosphorylating a set of substrates including PKB/Akt, PKC, and SGK1 [38]. Of note, Akt functions as the key downstream effector of insulin signaling to connect mTORC2 with glucose homeostasis, adipogenesis, diabetes, and cancers [39]. Different from mTORC1, mTORC2 is primarily activated by growth factors in a PI3K-dependent manner (Figure 3). Specifically, in the absence of growth factors, the Sin1-PH domain interacts with the mTOR kinase domain, leading to mTOR inactivation. Upon growth factor stimulation, activated PI3K produces phosphatidylinositol $(3,4,5)$-trisphosphate (PIP3), which interacts with the Sin1-PH domain and releases its inhibitory effect, thereby triggering mTORC2 activation [40]. In addition, the mTORC2 activation is also regulated by small GTPases, including Rac1, Rap1, and Ras [41,42]. 


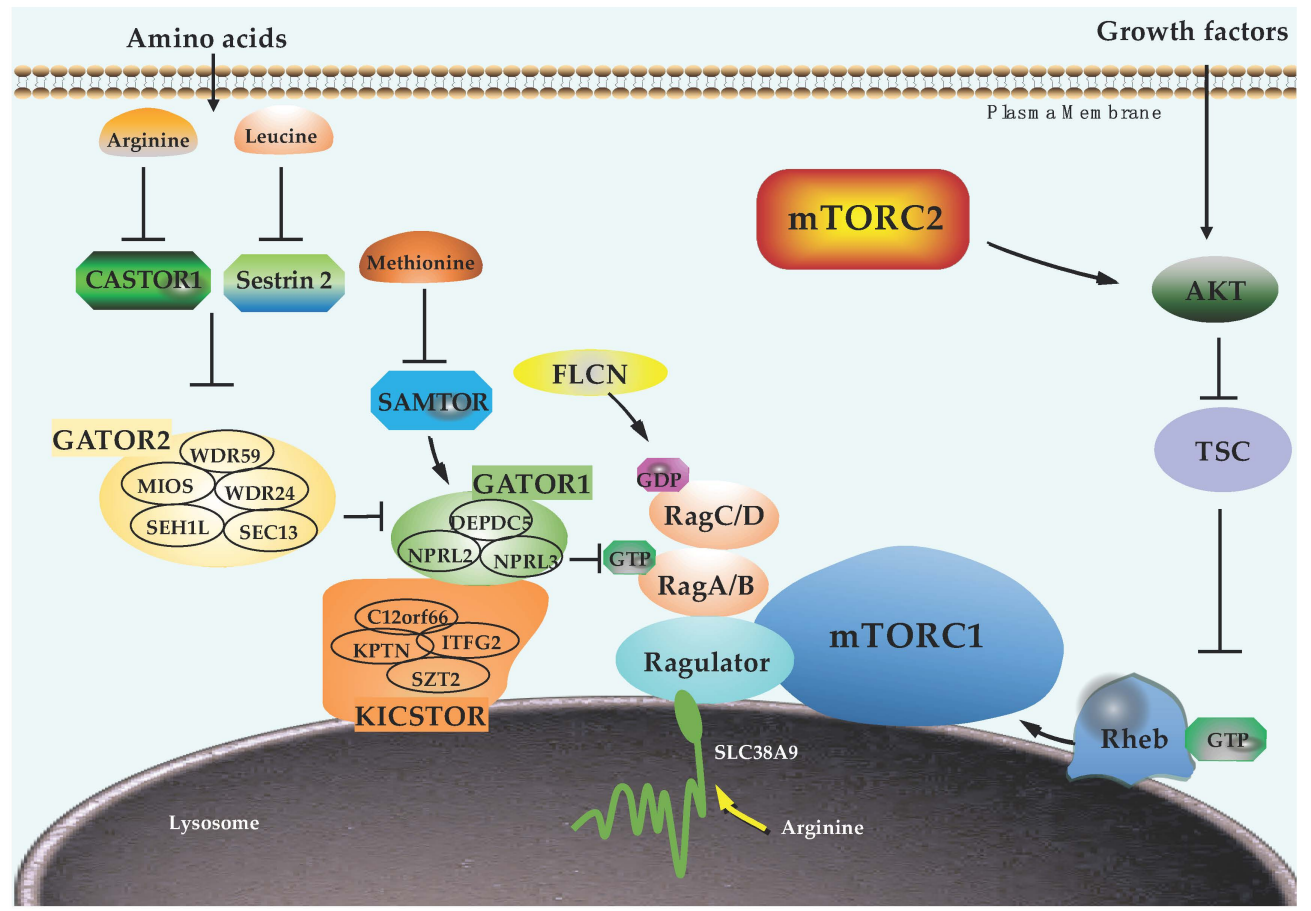

Figure 2. Amino acids and growth factors-mediated activation of the mTORC1 signaling. Amino acids bind to their specific sensors and transduce the signal through GATOR2, GATOR1, KICSTOR, and Ragulator complexes, leading to activation of Rag small GTPases and lysosomal recruitment of mTORC1. Growth factors activate other lysosomal localized small GTPases Rheb through Akt/TSC signaling axis. The small GTPases Rags and Rheb form two arms to fully activate mTORC1 pathway in response to amino acids and growth factors.

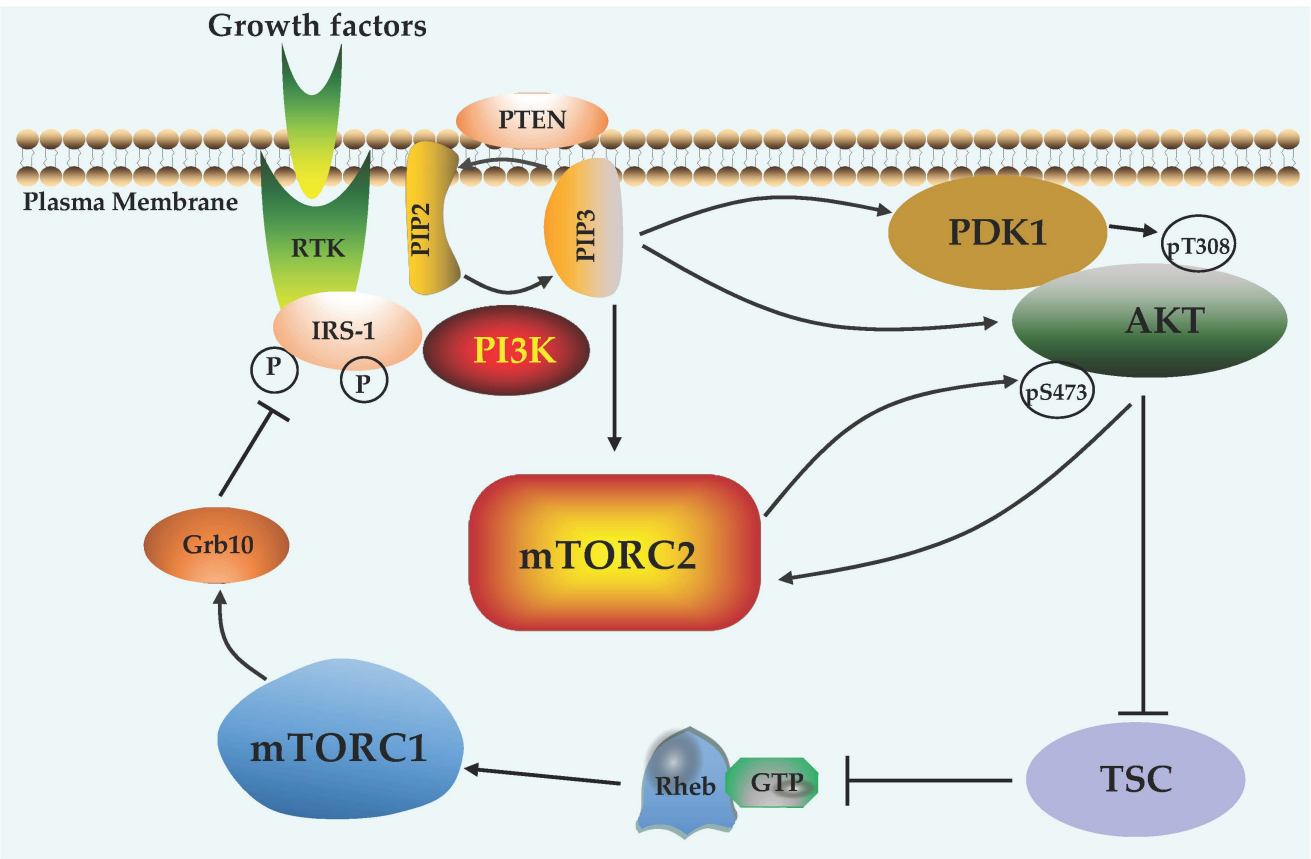

Figure 3. Crosstalk between mTOR signaling and PI3K/Akt pathway. Growth factors bind to receptor tyrosine kinase (RTK) and activate PI3K to convert PIP2 to PIP3, which can be reversed by PTEN. PIP3 recruits Akt to the plasma membrane for phosphorylation at T308 and S473 by PDK1 and mTORC2, respectively. Activated Akt suppresses TSC complex to promote GTP loading on Rheb for mTORC1 activation. In turn, mTORC1 phosphorylates Grb10 to inhibit RTK/PI3K activity. Thus, PI3K, Akt, and mTOR form a feedback regulatory loop. 
Having discovered dozens of proteins in the mTOR pathway, it is important to understand how these components are regulated, which may provide explanations for the aberrant mTOR signaling in human diseases. Besides genetic alterations and transcriptional regulations, post-translational modifications (PTMs) including phosphorylation, ubiquitination, acetylation, and glycosylation have been demonstrated to be key regulators of mTOR signaling. In this review, we will summarize PTMs-mediated regulation of the mTOR pathway (Table 1) and discuss strategies for targeting the mTOR pathway to treat human diseases.

\section{Roles of PTMs on Shared Components of the mTOR Signaling}

2.1. $m$ TOR

Studies have demonstrated that mTOR kinase activity can be regulated by several types of PTM, notably phosphorylation. Growth factors promote the phosphorylation of mTOR at S2448 by Akt or S6K1 [43-46], which is considered as a marker of mTORC1 activation. Moreover, nutrients deprivation induces AMPK-dependent phosphorylation of mTOR at S2446 [47]. Interestingly, phosphorylation of these two residues antagonizes each other, providing a switch to control mTOR activity by nutrients and growth factors. Furthermore, PI3K/Akt/TSC/Rheb signaling-mediated mTOR phosphorylation at S1261 enhances mTORC1 kinase activity and cell growth [48]. mTOR also undergoes autophosphorylation at S2481, which is mTORC2-dependent and wortmannin-sensitive, but rapamycin-, amino acid-, and serum-insensitive $[49,50]$. However, Soliman et al. reported that growth factors promote mTOR-S2481 phosphorylation in both mTORC1 and mTORC2 complexes and rapamycin treatment or amino acid deprivation blocks mTORC1associated S2481 phosphorylation [51]. Therefore, phosphorylation of mTOR-S2481 can be used as another marker of mTOR activation. In addition, dual phosphorylation of mTOR at S2159/T2164 weakens Raptor interaction with mTOR and PRAS40, leading to enhanced mTOR-S2481 autophosphorylation and mTORC1 intrinsic kinase activity [52]. Interestingly, levels of mTOR-pS2481 are significantly elevated in Alzheimer's disease (AD) and positively correlated with tau phosphorylation [53], while phosphorylation of mTOR-S2448 is stronger in metastatic cancer than in primary cancer of liver and kidney [54]. Ubiquitination is also a critical PTM in regulating mTOR activation. The E3 ubiquitin ligase FBXW7 promotes mTOR ubiquitination and subsequent proteasome-mediated degradation, leading to termination of mTOR signaling $[55,56]$. Consistently, frequent loss of FBXW7 in breast cancers is associated with hyperactivation of $\mathrm{mTORC} 1$ and increases sensitivity to rapamycin [55]. Moreover, Parkin-catalyzed polyubiquitination at K2066 and K2306 is required for mTORC1 activation and cell survival under mitochondrial stress [57]. In addition, malonylation of mTOR at K1218 attenuates its kinase activity in FASN-depleted endothelial cells and contributes to vascular defects [58]. Therefore, these diverse PTMs confer flexible regulation of mTOR signaling in response to environmental inputs.

\section{2. $m L S T 8$}

As the shared subunit of the mTORC1 and mTORC2 complexes, mLST8 was initially identified to bind to the mTOR kinase domain and stabilize mTOR interaction with Raptor, leading to enhanced mTORC1 activity toward S6K1 and 4E-BP1 [59]. However, loss of mLST8 only abrogates the integrity and activity of mTORC2, but not mTORC1 in mice [60,61]. A recent study revealed that TRAF2/OTUD7B-modulated K63-linked polyubiquitination of mLST8 at K305/K313 serves as a switch to govern the balance between mTORC2 and mTORC1. Specifically, mLST 8 ubiquitination by TRAF2 disrupts mTORC2 complex integrity by precluding Sin1 and Rictor binding to mTOR, and on the other hand, it promotes mTORC1 complex formation through enhancing mTOR interaction with Raptor. As a result, loss of mLST8 ubiquitination by either mutating the K305/K313 or depleting the E3 ligase TRAF2 enhances mTORC2 activation and tumor growth, while knockout of the deubiquitinase OTUD7B exhibits opposite phenotypes [62]. These studies indicate that mLST8 is indispensable for mTORC2 activation and tumor growth. In addition, $m L S T 8$ 
knockout mice are defective in vascular development [60], indicating it may be involved in vascular diseases.

\subsection{DEPTOR}

DEPTOR, also known as DEPDC6, is an mTOR-interacting protein that serves as an endogenous inhibitor of both mTORC1 and mTORC2. DEPTOR depletion enhances mTOR signaling, cell growth, and survival. In contrast, DEPTOR overexpression blocks mTORC1 activation but unexpectedly activates mTORC2 signaling through relieving the mTORC1mediated inhibitory feedback signal to the PI3K/mTORC2/Akt pathway [12]. Generally, DEPTOR expression is frequently decreased in most cancers but is upregulated in multiple myeloma, thyroid cancer, and lung cancer [63]. Thus, DEPTOR can be an oncogene or tumor suppressor. Interestingly, mTOR phosphorylates DEPTOR at $13 \mathrm{~S} / \mathrm{T}$ residues in the linker between the DEP domain and PDZ domain. This phosphorylation event collaborates with casein kinase I to generate a degron that can be recognized by the E3 ubiquitin ligase $\mathrm{SCF}^{\beta-\mathrm{TRCP}}$, resulting in its ubiquitination and degradation [64-66]. Moreover, $\mathrm{p} 38 \gamma$ or p388-mediated phosphorylation of DEPTOR also induces its degradation, leading to heart hypertrophy [67]. These studies suggest that aberrant DEPTOR expression contributes to the deregulation of mTOR signaling in human diseases.

\section{Regulation of Components in mTORC1 Pathway by PTMs}

3.1. Raptor

Raptor is the unique subunit of the mTORC1 complex and acts as a scaffolding protein to determine mTORC1 activity and substrate specificity $[4,5,9,10]$. Studies showed that conditional ablation of Raptor in mouse leads to various tissue-specific diseases, such as heart failure [68], hepatic steatosis [69], and muscle atrophy [70]. Unexpectedly, liver-specific Raptor-knockout promotes liver cancer development [71]. Similar to mTOR, extensive studies focused on the role of phosphorylation in regulating Raptor for mTORC1 activation. In response to upstream inputs such as insulin, amino acids, and energy, Raptor is phosphorylated at S863 and other multiple residues (S696, T706, S855, S859, and S877), deficiency of which leads to a reduction in mTOR kinase activity [72]. JNK, RSKs, and cdc2 have been reported to directly phosphorylate these sites under different conditions including osmotic stress, MAPK signaling activation, and mitosis [73-77]. Another important phosphorylation event on Raptor occurs under energy stress. Specifically, the cellular energy sensor AMPK directly phosphorylates Raptor at two well-conserved serine residues S722 and S792, which induces Raptor interaction with 14-3-3 protein, leading to mTORC1 inactivation and cell cycle arrest. Therefore, phosphorylation of S722/S792 serves as a checkpoint to coordinate cell growth with energy status [78]. Recently, Raptor was reported to be directly phosphorylated at S606 by the Hippo pathway core component LATS kinase in response to cellular inhibitory signals, resulting in attenuation of the mTORC1 kinase activity. This study provides a direct connection between the mTORC1 and the Hippo pathways to coordinately dictate cell growth, cell proliferation, and organ growth [79]. Other PTMs including ubiquitination and acetylation of Raptor also play critical roles on mTORC1 activation. For example, DDB1/CUL4-mediated polyubiquitination of Raptor enhances the stability and activity of the mTORC1 complex, which can be antagonized by the ubiquitin hydrolase UCH-L1 [80,81]. Sung et al. reported that acetyl-coenzyme A, the metabolite of leucine, can induce the EP300-depedent acetylation of Raptor. As a result, leucine deprivation decreases Raptor acetylation, leading to mTORC1 inhibition and autophagy induction [82].

\subsection{PRAS40}

In 2007, three independent groups identified PRAS40 as a Raptor-interacting protein that acts as an inhibitor to block insulin/Rheb-mediated activation of mTORC1 signaling [83-85]. In response to growth factors stimulation, PRAS40 is phosphorylated on multiple residues, which promotes its binding to $14-3-3$ protein and dissociation from the 
mTORC1 complex. Several kinases have been reported to participate in PRAS40 phosphorylation including Akt and PIM1 for T246, mTORC1 for S183 and S221, and PKM2 for S202/203 [86]. Importantly, elevated PRAS40-T246 phosphorylation was observed in several cancer types including malignant melanoma [87], prostate cancer [88], gastric cancer [89], and NSCLC [90]. Moreover, induction of PRAS40-T246 phosphorylation enhances insulin sensitivity in obese patients with type 2 diabetes [91]. In addition, PRAS40 has protective roles in neurodegenerative diseases and cardiovascular diseases [92]. Therefore, phosphorylation of PRAS40-T246 can be used as a biomarker for predicting the efficacy of inhibitors targeting the Akt/mTOR pathway in human diseases.

\subsection{TSC Complex}

TSC complex, composed of TSC1, TSC2, and TBC1D7, is a negative regulator of mTORC1 signaling [93]. Mutations or loss of TSC1/2 lead to hyperactivation of mTORC1 signaling and have been associated with many human disorders, such as lymphangioleiomyomatosis (LAM) and autism [94]. The TSC complex possesses GAP activity to convert Rheb from the active GTP-bound form to the inactive GDP-bound form [95]. Studies showed that in response to growth factor stimulation, phosphorylation of TSC at several sites by multiple kinases inhibits its GAP function and subsequently, relieves its inhibition on mTORC1 signaling, including Akt-mediated phosphorylation of S939/T1462, ERK-mediated phosphorylation of S664, and RSK1-mediated phosphorylation of S1798 [25,26,96-98]. In contrast, energy deprivation induces AMPK-dependent phosphorylation of TSC2 at S1387 and enhances TSC GAP activity, which in turn inactivates mTORC1 and protects cells from apoptosis [99]. These phosphorylation events represent key mechanisms for growth factors- or energy-regulated mTORC1 activation. In addition, IKK $\beta$-mediated phosphorylation of TSC1 at S487/S511 leads to TSC1 inhibition and mTORC1 activation, which promotes angiogenesis and tumor development [100]. Notably, TSC1/2 are ubiquitinated and degraded by multiple E3 ligases including TRIM31 [101], Pam [102], E6AP [103], and DDB1-CUL4-ROC1 [104], resulting in mTORC1 activation.

\subsection{Rheb GTPase}

Rheb is a small GTPase that is enriched on multiple endomembrane compartments including the lysosomal membrane where it interacts with and activates mTORC1. Farnesylation of Rheb in the C-terminal CaaX motif is required for its lysosomal localization $[105,106]$. In contrast, PRAK-mediated S130 phosphorylation inhibits GTP loading on Rheb under energy-deficient conditions, providing an AMPK-independent mechanism for mTORC1 inhibition by energy stress [107]. The nucleotide-loading status of Rheb is also regulated by RNF152-catalyzed ubiquitination at K8, which keeps Rheb in the inactive GDP-bound form to suppress mTORC1 activation [108]. A recent study showed that amino acids promote Rheb polyubiquitination to enhance its interaction with mTORC1. Interestingly, the ubiquitinated Rheb is subsequently degraded due to the loss of protection by the ATXN3 deubiquitinase that is dissociated from the lysosome by the active Rag GTPases [109]. Rheb functions as an oncogene, which is overexpressed in many cancers including prostate cancer and liver cancer [110]. Moreover, dysregulation of Rheb has also been linked to neurodegenerative diseases such as Parkinson's disease (PD) and AD [111]. Therefore, Rheb and its regulatory PTM enzymes are potential therapeutic targets.

\subsection{Rag GTPases}

The activation of the Rag heterodimer is the key step for mTORC1 lysosomal recruitment and activation. Notably, RagC is frequently mutated in follicular lymphoma [112] and the RagC-S75Y mutation is associated with the development of syndromic fetal dilated cardiomyopathy [113]. Several lines of evidence demonstrate that PTMs play a critical role in timely controlling Rags activation by amino acids. K63-linked polyubiquitination of RagA by E3 ligases RNF152 and Skp2 serves as an anchor to facilitate recruitment of GATOR1 and RagA GTP hydrolysis, leading to inactivation of mTORC1 signaling $[114,115]$. However, the specific mechanisms are different in these studies. Deng et al. showed that 
amino acid starvation induces RNF152-mediated polyubiquitination of RagA at four sites (K142/K220/K230/K244) and RNF152 knockout leads to hyperactivation of mTORC1 [114]. In contrast, Jin et al. demonstrated that amino acid stimulation promotes Skp2-dependent RagA polyubiquitination, which acts as a negative feedback signal to terminate amino acid-induced mTORC1 activation [115]. However, whether and how RNF152 and Skp2 coordinately regulate RagA polyubiquitination in response to amino acid remain elusive. Interestingly, insulin induces mTORC1-dependent phosphorylation of RagC at three highly conversed sites (S2, S21, and T394). Deficiency in this phosphorylation attenuates mTORC1 maximal activation by altering mTOR and Raptor interaction. This study reveals another crosstalk between amino acid and growth factor-stimulated mTORC1 signaling [116].

\subsection{Ragulator Complex}

Ragulator interacts with Rag GTPases and is necessary for localizing the Rag proteins and $\mathrm{mTORC} 1$ to the lysosomal surface for activation. Among the five components of the Ragulator complex, myristoylation and palmitoylation in the N-terminus of p18 serve as a membrane localization signal for tethering Ragulator to the lysosomal surface [117]. Moreover, the protein stability of p18 is controlled by the E3 ubiquitin ligase UBE3A through the ubiquitination-proteasome system [118]. As imbalance in UBE3A is associated with Angelman syndrome and autism $[119,120]$, this finding indicates that aberrant expression of p18/Ragulator may contribute to neurological disorder. A structural study also identified that C7orf59 is phosphorylated at $\mathrm{S} 67$ by PKA, which disrupts its interaction with p18. However, it is unknown whether $\mathrm{S} 67$ phosphorylation is regulated by amino acid and controls mTORC1 signaling [121].

\subsection{GATOR1, GATOR2, and KICSTOR Complexes}

The GATOR1 complex is composed of three subunits including DEPDC5, NPRL2, and NPRL3, while the GATOR2 complex consists of WDR24, WDR59, MIOS, SEH1L, and SEC13 [29]. KISCTOR was recently identified as a four-protein complex containing SZT2, KPTN, ITFG2, and C12orf66 [30,31]. These three complexes form a huge complex to regulate amino acid-mediated mTORC1 signaling. Specifically, SZT2 serves as the platform to directly connect the other three components of KISCTOR and GATOR1 to the lysosomal membrane, while GATOR2 directly interacts with and inhibits GATOR1. Of note, the integrity of these complexes and their interactions are not affected by amino acids. Therefore, GATOR1 and KICSTOR are two negative regulators, whereas GATOR2 is a positive regulator of mTORC1 lysosomal localization and activation. To date, only DEPDC5 has been reported to be regulated by PTMs. Chen et al. showed that DEPDC5 is K48-linked and polyubiquitinated at multiple lysine residues by the E3 ubiquitin ligase KLHL22 upon amino acid stimulation and consequently decreases the DEPDC5 protein levels and activates mTORC1 signaling. Consistently, elevated KLHL22 expression is positively correlated with decreased DEPDC5 protein levels in tumor samples from breast cancer patients [122]. Pim and Akt kinases-mediated phosphorylation of DEPDC5-S1530 results in activation of mTORC1 in an amino acid-insensitive fashion. As a result, S1530A mutant significantly suppresses cell growth and tumorigenesis in part due to the deficiency in mTORC1 signaling [123]. However, the molecular mechanism underlying how DEPDC5 phosphorylation promotes mTORC1 activation is unknown. Recently, mutations in the GATOR1 subunits and SZT2 are linked to epilepsy [124,125]. Thus, it will significantly expand our knowledge on mTORC1 pathway regulation if we can reveal more PTMs on these complexes.

\subsection{FLCN}

FLCN is considered as a tumor suppressor, mutations in which are the drivers of Birt-Hogg-Dubé hereditary cancer syndrome [126]. Moreover, cardiac-specific knockout of FLCN leads to cardiac hypertrophy and dysfunction in mice [127]. FLCN functions as a GAP for RagC/ $\mathrm{D}^{\mathrm{GTP}}$ hydrolysis in the presence of amino acids [21]. FLCN was 
reported to be phosphorylated at multiple residues including S62/S73 by mTORC1 [128], S406/S537/S542 by ULK1 [129], and S302 by unknown kinase [130]. FLCN has also been found to be ubiquitinated at K206/K559 by mass spectrometric analysis [131,132]. However, whether phosphorylation and ubiquitination of FLCN regulate mTOR signaling have not yet been investigated.

\subsection{Amino Acid Sensors}

To date, three types of cytosolic amino acid sensors for the mTORC1 pathway have been identified: the leucine sensor Sestrin2, arginine sensor CASTOR1, and S-adenosylmethionine (SAM) sensor SAMTOR [133]. Mechanically, in the absence of leucine, Sestrin2 interacts with GATOR2 to release its inhibition on GATOR1, and consequently inactivates Rags-mediated mTORC1 signaling. Conversely, in the presence of leucine, Sestrin 2 binds to leucine and dissociates from GATOR2, leading to GATOR2-dependent activation of mTORC1 signaling [33]. CASTOR1 applies the same mechanism as Sestrin2 to regulate arginine-induced mTORC1 activation [35], while SAMTOR directly interacts with GATOR1 to regulate SAM-mediated mTORC1 regulation [34]. Emerging studies demonstrate that phosphorylation and ubiquitination of Sestrin2 play a critical role in regulating mTORC1 signaling. ULK1-mediated phosphorylation of Sestrin2 at S73/S254 enhances its interaction with GATOR2, leading to mTORC1 inhibition and autophagy induction [134,135]. The RING-type E3 ligase RNF186 promotes ubiquitination and degradation of Serstrin2, leading to hyperactivation of the mTORC1 pathway [136]. Notably, RNF186-A64T mutation is a risk factor for the development of ulcerative colitis (UC), a kind of inflammatory bowel disease (IBD) [137]. It will be interesting to investigate whether Sestrins2/mTORC1 signaling is involved in RNF186-A64T-associated UC. Moreover, the expression of Sestrins 2 is induced by stress, such as oxidative stress, genotoxic stress, and hypoxia, and exerts a protective role in cardiovascular and neurodegenerative diseases [138].

\subsection{0. mTORC1 Downstream Targets}

As a S/T protein kinase, mTORC1 exerts its biological functions on cell growth and metabolism by phosphorylating multiple downstream substrates, most of which have been demonstrated to play a role in various types of human diseases, such as cancers and cardiovascular and neurodegenerative diseases [3]. Here, we review the roles of PTMs on three critical mTORC1 downstream substrates.

The S6K kinases (S6K1 and S6K2) are critical downstream effectors of mTORC1 in controlling fundamental cellular processes, such as transcription, translation, metabolism, and cell growth [139]. Phosphorylation is the key mechanism regulating S6K1 activation [140]. In response to growth factors and nutrients, $\mathrm{S} 6 \mathrm{~K} 1$ is specifically phosphorylated at T389 by mTORC1 [141], followed phosphorylation at T229 by PDK1 [142,143]. Sequential phosphorylation at these two sites is essential for S6K1 full activation. In addition, phosphorylation at multiple sites in the C-terminal region also contributes to S6K1 activity [144]. Aside from phosphorylation, acetylation of S6K1 at the C-terminus by p300/PCAF attenuates mTORC1-dependent S6K1 phosphorylation [145], and polyubiquitination of S6K1 by E3 ubiquitin ligase ROC1 promotes its degradation [146].

ULK1, a gate keeper for autophagy initiation, is a key downstream effector mediating the role of mTORC1 signaling in autophagy. Upon glucose starvation, AMPK activates ULK1 by directly phosphorylating S317/S377 to induce autophagy. Conversely, under nutrient- and energy-rich conditions, mTORC1 directly phosphorylates ULK1 at S757 to disrupt ULK1 interaction with AMPK, leading to autophagy inhibition [147]. Recently, ULK1 was reported to be O-GlcNAcylated on T754 by OGT under glucose starvation, which cooperates with mTORC1/AMPK to induce autophagy [148]. Acetylation of ULK1 at K162/K606 by acetyltransferase TIP60 is also required for ULK1-mediated autophagy in response to growth factors withdrawal [149]. In addition, mTORC1/AMBRA1 coordinately regulates E3 ubiquitin ligase TRAF6-mediated K63-linked polyubiquitination of ULK1, which enhances ULK1 stability and function [150]. These studies suggested that mTORC1- 
mediated phosphorylation of ULK1 plays a key role in coordinating with other PTMs to control ULK1 activation and autophagy induction.

Grb10 is an adapter protein that interacts with tyrosine kinase receptors, such as insulin receptor [151]. mTORC1-mediated phosphorylation of Grb10 at S501/S503 increases its stability. Since Grb10 is a negative regulator of insulin signaling, Grb10 accumulation activates the negative feedback loop from mTORC1 to the PI3K/Akt pathway, leading to inactivation of PI3K/ Akt signaling [128].

\section{Regulation of Components in mTORC2 Pathway by PTMs 4.1. Rictor}

In searching the mTOR-interacting proteins, Rictor was identified as a novel mTORassociated component, which also binds to mLST8 and confers a rapamycin-insensitive feature to mTORC2 [7]. Acetylation and phosphorylation are two major modifications of Rictor. p300 promotes acetylation of Rictor at multiple sites including K1092, K1095, K1116, K1119, and K1125, which enhances mTORC2 kinase activity toward Akt in response to growth factor stimulation [152]. Notably, phosphorylation of Rictor by GSK3 at T1695 suppresses mTORC2 signaling through different mechanisms. T1695 phosphorylation primes for FBXW7-mediated ubiquitination and degradation of Rictor [153], which may account for the overexpression of Rictor in cancers [154]. S1235 phosphorylation impairs mTORC2 binding to Akt in vitro [155]. Rictor was also found to be phosphorylated at T1135 by S6K1. Mutating T1135 to alanine enhances Akt signaling induced by growth factors, although neither mTORC2 kinase activity and integrity nor cellular localization were affected by T1135 phosphorylation [156]. Interestingly, the total levels of Rictor and T1135 phosphorylation are downregulated in AD [157].

\section{2. $\operatorname{Sin} 1$}

Later studies characterized Sin1 as another essential component of the mTORC2 complex, the depletion of which abolishes mTORC2 complex formation [11,158]. Sin1 is frequently overexpressed in many cancer types and plays a critical role in cell proliferation, epithelial mesenchymal transition (EMT), and metastasis $[159,160]$. Sin1 phosphorylation has been found to have different impacts on mTORC2 activation. Dual phosphorylation of Sin 1 at T86/T398 by S6K1 or Akt dissociates Sin1 from mTORC2, leading to the inhibition of mTORC2 [161], whereas phosphorylation of Sin1 at T86 alone enhances mTORC2 kinase activity [162]. Therefore, $\operatorname{Sin} 1$ phosphorylation provides a delicate regulation of mTORC2 activation. Recently, Cui et al. reported that the CUL5-SOCS6 complex promotes Sin1 ubiquitination at K162, K276, and K302, leading to Sin1 degradation and mTORC2 inactivation [163].

\subsection{PI3K and PTEN}

It has been reported that the Sin1-PH domain binds to PIP3 and subsequently releases its inhibition on the mTOR kinase domain, leading to mTORC2 activation in response to growth factors [40]. Thus, the production of PIP3 is a critical step for mTORC2 activation. The PI3Ks are the lipid kinases that phosphorylate PIP2 at the plasma membrane to generate PIP3, which is antagonized by the lipid phosphatase PTEN. PI3Ks are frequently mutated or amplified, whereas PTEN is commonly deleted or mutated in many human diseases including but not limited to cancers, metabolic disorders, and AD [164]. In addition to genetic alterations, a number of studies have also demonstrated that PTMs including SUMOylation, phosphorylation, ubiquitination, and acetylation play important roles in regulating the activity and stability of PI3K and PTEN [165-168], which may play a role in regulating mTORC2 activation.

\section{4. mTORC2-Specific GTPases}

Like mTORC1, several small GTPases have been identified recently to directly regulate mTORC2 kinase activity. The Rho family of GTPase Rac1 directly binds to mTOR through 
the C-terminal region and promotes the activity of both mTORC1 and mTORC2 independent of its nucleotide binding states and PI3K pathway [41]. Of the Ras family of GTPases, Ras and Rit promote mTORC2 activation through interaction with Sin1 $[169,170]$. Despite multiple types of PTMs being reported to control the activation and cellular localization of Rac1 and Ras [171,172], it is unknown whether these PTMs are involved in regulating mTORC2 kinase activity. Fortunately, studies in Dictyostelium have provided more detailed knowledge on GTPase-mediated activation of mTORC2. The small GTPases, Rap1 and RasC, bind to Sin1 and the mTOR kinase domain, respectively, which cooperatively activate mTORC2 in response to chemoattractants [173]. Interestingly, GDP-bound RacE interacts with both Tor (mTOR homologue) and PiaA (Rictor homologue). Moreover, phosphorylation of RacE ${ }^{\mathrm{GDP}}$ at S192 by GSK3 mediates its interaction with RasC $\mathrm{C}^{\mathrm{GTP}}$ to promote mTORC2 activation [42]. These studies suggest that GTPases may control mTORC2 activity in a fashion similar to mTORC1.

\section{5. mTORC2 Downstream Effectors}

As a major substrate, Akt is phosphorylated at $\mathrm{S473}$ by mTORC2 [174], which cooperates with PDK1-mediated T308 phosphorylation to promote PI3K-dependent activation of Akt in response to growth factors [39]. Furthermore, many other PTMs have been identified to fine tune Akt kinase activity (review in [175]). Phosphorylation at S477/S479 by the cyclin A-CDK2 complex along with mTORC2-mediated S473 phosphorylation enhances Akt activation in a cell cycle-dependent manner [176]. K63-linked polyubiquitination of Akt in the PH domain by E3 ubiquitin ligases TRAF6 [177] and Skp2 [178] promotes Akt membrane localization and activation, leading to enhanced glycolysis and tumorigenesis. Recently, two groups independently demonstrated that SETDB1-mediated methylation of Akt at K64 or K140/K42 crosstalks with PI3K and TRAF6/Skp2 to promote Akt activation and tumor growth $[179,180]$. Interestingly, hydroxylation of Akt at P125/P313 by the prolyl hydroxylase EglN1 triggers its interaction with E3 ubiquitin ligase VHL, leading to Akt inhibition independent of its ubiquitination [181]. As these PTM enzymes are frequently deregulated, these studies provide multiple mechanisms for hyperactivation of Akt in cancers, metabolic disorders, and other diseases [182].

Besides Akt, PKCs and SGK1 are also the downstream effectors of mTORC2. Phosphorylation of PKC $\alpha$ by mTORC2 in the turn motif promotes its maturation, stabilization, and activation, which controls actin polymerization, cell shape, and mobility $[60,183,184]$. Moreover, other PTMs including ubiquitination, O-GlcNAc, tyrosine nitration, and tyrosine phosphorylation also play a role in regulating PKC functions $[185,186]$. Phosphorylation of SGK1 at the hydrophobic motif by mTORC2 promotes its activation [187]. SGK1 is polyubiquitinated and rapidly turned over by different E3 ubiquitin ligases including CHIP, HRD1, NEDD4L, and Rictor/Cullin 1 [188]. 
Table 1. Major post-translational modifications (PTMs) of the mTOR signaling pathway.

\begin{tabular}{|c|c|c|c|c|c|}
\hline Target & PTM & Sites & Enzyme & Influence on mTOR & References \\
\hline mTOR & phosphorylation & S2448 & AktS6K1 & activation & [43-46] \\
\hline mTOR & phosphorylation & S2446 & AMPK & inhibition & [47] \\
\hline mTOR & phosphorylation & S1261 & PI3K/TSC & activation & [48] \\
\hline mTOR & phosphorylation & S2159/T2164 & unknown & activation & [52] \\
\hline mTOR & ubiquitination & unknown & FBXW7 & inhibition & {$[55,56]$} \\
\hline mTOR & ubiquitination & K2066/K2306 & Parkin & activation & {$[57]$} \\
\hline mTOR & malonylation & K1218 & unknown & inhibition & [58] \\
\hline mLST8 & ubiquitination & K305/K313 & TRAF2 & inhibition & [62] \\
\hline mLST8 & deubiquitination & K305/K313 & OTUD7B & activation & [62] \\
\hline DEPTOR & ubiquitination & unknown & $\mathrm{SCF}^{\beta-\mathrm{TRCP}}$ & activation & [64-66] \\
\hline DEPTOR & phosphorylation & multiple S/T & 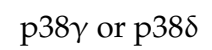 & activation & [67] \\
\hline Raptor & phosphorylation & S696/T706/S863 & JNK & activation & {$[73,74]$} \\
\hline Raptor & phosphorylation & multiple S & cdc2 & activation & {$[75,76]$} \\
\hline Raptor & phosphorylation & S719/S721/S722 & RSKs & activation & [77] \\
\hline Raptor & phosphorylation & S722/S792 & AMPK & inhibition & [78] \\
\hline Raptor & phosphorylation & S606 & LATS & inhibition & [79] \\
\hline Raptor & ubiquitination & unknown & UCH-L1 & inhibition & [81] \\
\hline Raptor & acetylation & unknown & EP300 & activation & [82] \\
\hline PRAS40 & phosphorylation & $\mathrm{T} 246$ & Akt or PIM1 & activation & [86] \\
\hline PRAS40 & phosphorylation & S183/S221 & mTORC1 & activation & [86] \\
\hline PRAS40 & phosphorylation & S202/S203 & PKM2 & activation & [86] \\
\hline TSC & phosphorylation & S939/T1462 & Akt & inhibition & {$[25,26]$} \\
\hline TSC & phosphorylation & S664 & ERK & inhibition & {$[96,97]$} \\
\hline TSC & phosphorylation & S1798 & RSK1 & activation & [98] \\
\hline TSC2 & phosphorylation & S1387 & AMPK & inhibition & [99] \\
\hline TSC1 & phosphorylation & S487/S511 & IKK $\beta$ & activation & [100] \\
\hline $\mathrm{TSC} 1 / 2$ & ubiquitination & unknown & TRIM31 & activation & [101] \\
\hline TSC & ubiquitination & unknown & Pam & activation & [102] \\
\hline TSC2 & ubiquitination & unknown & E6AP & activation & [103] \\
\hline TSC2 & ubiquitination & unknown & DDB1/ROC1 & activation & [104] \\
\hline
\end{tabular}


Table 1. Cont.

\begin{tabular}{|c|c|c|c|c|c|}
\hline Target & PTM & Sites & Enzyme & Influence on mTOR & References \\
\hline Rheb & farnesylation & unknown & unknown & activation & {$[105,106]$} \\
\hline Rheb & phosphorylation & S130 & PARK & inhibition & [107] \\
\hline Rheb & ubiquitination & K8 & RNF152 & inhibition & [108] \\
\hline $\operatorname{Rag} A$ & ubiquitination & multiple lysine & RNF152 & inhibition & [114] \\
\hline $\operatorname{Rag} A$ & ubiquitination & unknown & Skp2 & inhibition & [115] \\
\hline $\operatorname{Rag} C$ & phosphorylation & S2/S21/T394 & mTORC1 & activation & [116] \\
\hline p18 & palmitoylation & unknown & unknown & activation & [117] \\
\hline $\mathrm{p} 18$ & ubiquitination & unknown & UBE3A & inhibition & [118] \\
\hline C7orf59 & phosphorylation & S67 & PKA & unknown & [121] \\
\hline DEPDC5 & ubiquitination & multiple lysine & KLHL22 & activation & [122] \\
\hline DEPDC5 & phosphorylation & S1530 & Pim/Akt & activation & [123] \\
\hline FLCN & phosphorylation & S62/S73 & mTORC1 & unknown & [128] \\
\hline FLCN & phosphorylation & S406/S537/S542 & ULK1 & unknown & [129] \\
\hline FLCN & phosphorylation & S302 & unknown & unknown & [130] \\
\hline Sestrin2 & phosphorylation & S73/S254 & ULK1 & inhibition & {$[134,135]$} \\
\hline Sestrin2 & ubiquitination & K13 & RNF186 & inhibition & [136] \\
\hline S6K1 & phosphorylation & T389 & mTORC1 & activation & [141] \\
\hline S6K1 & phosphorylation & T229 & PDK1 & activation & {$[142,143]$} \\
\hline S6K1 & acetylation & C-terminal & p300/PCAF & inhibition & [145] \\
\hline S6K1 & ubiquitination & unknown & ROC1 & inhibition & [146] \\
\hline ULK1 & phosphorylation & S317/S377 & AMPK & activation & [147] \\
\hline ULK1 & phosphorylation & S757 & mTORC1 & inhibition & [147] \\
\hline ULK1 & O-GlcNAcylation & T754 & OGT & activation & [148] \\
\hline ULK1 & acetylation & K162/K606 & TIP60 & activation & [149] \\
\hline ULK1 & ubiquitination & unknown & TRAF6 & inhibition & [150] \\
\hline
\end{tabular}


Table 1. Cont

\begin{tabular}{|c|c|c|c|c|c|}
\hline Grb10 & phosphorylation & S501/S503 & mTORC1 & inhibition & [128] \\
\hline Rictor & acetylation & multiple lysine & p300 & activation & [152] \\
\hline Rictor & phosphorylation & T1695 & GSK3 & inhibition & [153] \\
\hline Rictor & phosphorylation & S1235 & Akt & inhibition & [155] \\
\hline Target & PTM & Sites & Enzyme & Influence on mTOR & References \\
\hline $\operatorname{Sin} 1$ & phosphorylation & T86/T398 & S6K1 or Akt & inhibition & [161] \\
\hline $\operatorname{Sin} 1$ & phosphorylation & $\mathrm{T} 86$ & Akt & activation & [162] \\
\hline $\operatorname{Sin} 1$ & ubiquitination & multiple lysine & CUL5-SOC6 & inhibition & [163] \\
\hline Akt & phosphorylation & S477/S479 & cyclin A/CDK2 & activation & [176] \\
\hline Akt & ubiquitination & unknown & TRAF6, Skp2 & activation & {$[177,178]$} \\
\hline Akt & methylation & K64/K140/K42 & SETDB1 & activation & {$[179,180]$} \\
\hline Akt & hydroxylation & P125/P313 & EglN1 & inhibition & [181] \\
\hline $\mathrm{PKC} \alpha$ & phosphorylation & unknown & mTORC2 & activation & {$[60,183,184]$} \\
\hline SGK1 & phosphorylation & unknown & mTORC2 & activation & [187] \\
\hline
\end{tabular}




\section{Targeting mTOR Signaling for Treating Human Diseases}

\section{1. mTOR Specific Inhibitors}

Dysregulation of mTOR signaling is tightly associated with many human diseases, such as obesity, diabetes, cancers, and neuronal disorders [3], making mTOR an ideal therapeutic target. Extensive efforts have focused on the development of mTOR inhibitors. Rapamycin and its derivatives (termed as Rapalogs) are the first generation of mTOR inhibitors. Rapamycin was originally identified as an antifungal and immunosuppressive drug and was approved by the FDA to use for preventing allograft rejection in transplantation and restenosis in coronary artery stents, but not for cancer treatment due to its poor solubility [189]. To date, several water-soluble Rapalogs have been developed and are evaluated in many clinical trials. Notably, Temsirolimus and Everolimus have been approved by the FDA for treating advanced renal cell carcinoma [190]. However, their anti-tumor efficacy is modest and Rapalog resistance is frequently acquired in the majority of solid tumors. One of the causes is that Rapalogs only partially inhibit mTORC1 but not mTORC2 [191]. To resolve this drawback, the secondary generation of ATP-competitive mTOR inhibitors (TORKi) has been developed to target both mTORC1 and mTORC2. Preclinical studies showed that these pan-mTOR inhibitors can overcome Rapalog resistance and are currently being evaluated in clinical trials [192-194]. However, an emerging study demonstrated that acquired mutations in mTOR result in hyperactivation of mTOR kinase and confer resistance to both rapalogs and TORKi [195]. To overcome the resistance, a third generation of mTOR inhibitor was generated by crosslinking rapamycin with a TORKi named Rapalink [195]. Importantly, Rapalink exhibits better anti-tumor efficacy than rapamycin or TORKi in glioblastoma [196].

\subsection{Dual PI3K/mTOR Inhibitors}

Despite TORKi being able to block mTORC2-dependent phosphorylation of Akt-S473, its inhibition on mTORC1 may release the negative feedback regulation of PI3K/PDK1/Akt signaling [197,198], consequently attenuating the efficacy or acquiring resistance to TORKi [199]. Given the similarity of structural kinase domain between PI3K and mTOR, compounds targeting both kinases have been developed. Notably, Dactolisib (BEZ235 and NVP-BEZ235) was the first dual PI3K/mTOR inhibitor entering clinical trials. However, limited anti-tumor effect and poor tolerance have been reported in the treatment of prostate cancer, pancreatic neuroendocrine tumor, advanced breast cancer, and advanced renal cancer [200-202]. Currently, several clinical trials of dual PI3K/mTOR inhibitors including GDC-0980 (Apitolisib) and PF-04691502 and PF-05212384 (Gedatolisib) either in monotherapy or in combination therapies are ongoing [203]. Since PI3K and the mTOR pathway are critical for cell growth and metabolism, inhibition of both may increase toxicity and adverse effects. Therefore, balance between the anti-tumor activity and dose-tolerability has to be seriously considered in clinical trials with these dual $\mathrm{PI} 3 \mathrm{~K} / \mathrm{mTOR}$ inhibitors.

\subsection{Akt Inhibitors}

As the major downstream effector of PI3K/mTOR signaling, Akt plays a central role in promoting cell survival and apoptosis. Given hyperactivation of Akt is a hallmark of cancers, targeting Akt for cancer therapy has been extensively investigated [39]. Many Akt inhibitors including AZD5363, MK2206, and GDC-0068 are in phase I/II clinical trials, especially for breast cancers [204-206]. However, none of these inhibitors have achieved satisfactory outcomes in monotherapy and entered phase III clinical trials, which is largely due to the complexity of Akt signaling and toxicity. In the human genome, Akt has three isoforms that possess different localizations, substrates, and biological functions [207]. Thus, development of Akt isoform-specific inhibitors may be helpful to tackle complicated Akt signaling. In addition, the combination of Akt inhibitors with chemotherapy and other targeted therapy is an option for reducing toxicity [208]. 


\subsection{Targeting mTOR Signaling Regulators}

As the key events in signaling transduction, PTMs including phosphorylation, ubiquitination, methylation, and acetylation, among others, provide a tight and reversible regulation of mTOR signaling. Aberrancies in these PTM-related enzymes may lead to the aberrant activation of the mTOR pathway. Therefore, targeting these mTOR-related regulators would offer an option for treating mTOR-associated human diseases. Below, we primarily focus on kinases, E3 ubiquitin ligases, and deubiquitinases, which are key regulators of the mTOR pathway.

\subsubsection{Kinases}

As S/T kinases, RSKs regulate diverse cellular processes by phosphorylating many downstream substrates [209]. Notably, RSKs promote cell growth and protein synthesis by activating the mTORC1 pathway through phosphorylating both TSC2 and Raptor as described previously. Of note, hyperactivation of RSKs has been implicated in various types of diseases, such as cancers, cardiovascular diseases, and liver and kidney diseases. Several pan-RSK inhibitors have been developed and have shown promising results in preclinical models [210]. SL0101 significantly suppresses breast cancer cell proliferation and tumor growth. BIX02565 reduces cardiac ischemia/reperfusion injury, and BI-D1870 attenuates autoimmune encephalomyelitis in mice. However, further studies and more specific and efficient RSK inhibitors are needed to target RSKs for clinically treating human diseases.

JNKs including JNK1, JNK2, and JNK3 in mammals are predominantly activated by environmental stress and regulate many physiological processes, such as cell proliferation, apoptosis, immune response, inflammation, and neuronal plasticity [211]. Their hyperactivation is associated with a multitude of diseases including cancers, diabetes, autoimmune disease, and neurological disorders, particularly AD [212]. Thus, JNKs are potential therapeutic targets. A number of JNK inhibitors have been extensively investigated in preclinical models of human diseases and several of them have entered clinical trials [213]. However, most of the trials seem to achieve limited success largely due to sequence similarity but also the functional diversity of the three JNKs in different tissues/diseases. Therefore, isoform-specific JNK inhibitors would facilitate their clinical applications.

The PIM kinase family containing three members, PIM1-3, and plays a critical role in cell proliferation, apoptosis, and migration by directly phosphorylating a number of downstream targets, such as MYC, CDC25, p21/p27, and TSC2. Overexpression of PIM kinases has been observed in a variety of human cancers and is associated with poor prognosis and drug resistance in prostate cancer and breast cancer [214]. As there have been significant advances in understanding the oncogenic role of PIM kinase in the past decade, several promising PIM kinase inhibitors have been developed and evaluated in clinical trials for prostate cancer, acute myelogenous leukemia, and multiple myeloma [215]. Notably, panPIM inhibitor LGH447 was generally well tolerated and exhibited a promising therapeutic outcome in multiple myeloma patients. Moreover, clinical trials for a combination of LGH447 with PI3K inhibitor (BYL719) or CDK4/6 inhibitor (LEE011) are ongoing [216].

Other mTOR pathway-associated kinases including cdc2 [217], IKK $\beta$ [218], AMPK [219], LATS [220], ULK1 [221], and GSK3 [222] have been implicated in human diseases. AMPK plays a central role in maintaining cellular energy homeostasis and its inactivation may lead to metabolic disorders including diabetes, obesity, liver, and kidney diseases. Thus, pharmacological activation of AMPK has gained extensive attention in the past five years. A number of direct or indirect AMPK activators have been approved for use or are in clinical trials [219]. ULK1 is a critical S/T protein kinase for autophagy initiation, which is a substrate and a negative regulator of mTORC1. ULK1-mediated autophagy can either promote tumor progression or suppress tumor growth, as well as confer drug resistance [221]. ULK1 inhibitors including ULK-101, MRT68921, and SBI-0206965 significantly suppress cancer cell proliferation and induce apoptosis $[223,224]$, which is worth further investigation in mice models. 


\subsubsection{E3 Ubiquitin Ligases and Deubiquitinases (DUBs)}

As described above, a dozen E3 ligases and DUBs have been identified to regulate mTOR signaling by controlling protein stability, enzymatic activity, and complex formation. Aberrancies in these E3s/DUBs are frequently observed in human diseases, which may be in part responsible for the dysregulation of mTOR signaling.

FBXW7, a cullin-based SCF type of E3 ubiquitin ligase, plays an important role in various biological processes such as cell cycle transition, cell proliferation, apoptosis, metastasis, and immune response [225]. FBXW7 is a well-acknowledged tumor suppressor that promotes the degradation of multiple oncogenic proteins such as cyclin E, MCL1, c-Myc, mTOR, and Rictor. Consistently, FBXW7 is frequently lost or mutated in various types of cancers. Notably, more than $30 \%$ of $\mathrm{T}$ cell acute lymphoblastic leukemia and cholangiocarcinomas harbor FBXW7 mutations [225]. Beside cancers, loss of FBXW7 also contributes to other mTOR-related diseases, such as metabolic disorders and aging, which warrants further studies.

Parkin belongs to the RING-between-RING (RBR) family of E3 ubiquitin ligases that regulate a variety of cellular processes including mitochondrial quality control, antioxidative stress, and mitophagy. Mutations in Parkin lost its protective role on the survival of dopaminergic neurons, which is the major cause of autosomal recessive parkinsonism. Notably, mTOR signaling exerts either a neuroprotective or neurotoxic role depending on PD models and has been linked to PD. It will be interesting to investigate whether Parkinmediated ubiquitination and activation of mTOR signaling play a role in PD. Moreover, Parkin is an emerging tumor suppressor as it is frequently lost in cancers including breast, lung, colorectal, and ovarian cancers [226]. Consistently, Parkin knockout mice develop hepatocellular carcinoma [227]. However, the exact mechanisms underlying how Parkin suppresses tumor growth is largely unknown. It is possible that Parkin-mediated regulation of mTOR signaling contributes to its tumor suppressive function.

Other E3 ubiquitin ligases including Skp2 [228] and KLHL22 [122] are oncoproteins, which are overexpressed in many cancers. Several Skp2 inhibitors including compound 25 [229], compound A [230], and compound C [231] exhibit significant anti-growth/tumor effects in cancer cells and mouse models. In contrast, the E3 ligase RNF152 suppresses both amino acids and growth factors-induced mTORC1 activation by inhibiting the critical GTPases RagA and Rheb, respectively. Downregulation of RNF152 results in the hyperactivation of mTORC1, which has been observed in a variety of cancers including colon, lung, kidney, and liver cancers [232]. TRAF2 is a crucial inflammatory regulator that activates multiple signaling pathways including NF- $\mathrm{kB}$, MAPKs, and IRFs. Upregulation of TRAF2 has been linked to multiple inflammatory diseases, such as atherosclerosis, AD, PD, and multiple sclerosis [233]. In addition to inflammation, TRAF2 also plays a tumor suppressive or oncogenic role in different types of cancers [234].

OTUD7B belongs to the ovarian tumor (OUT) family of deubiquitinases and prefers to hydrolyze the K63-linked ubiquitin chain [235]. OTUD7B has been demonstrated to have a crucial role in inflammatory and immune response through the NF-KB pathway $[236,237]$. Recent studies suggested that OTUD7B may promote cancer progression by activating oncogenic pathways including EGFR and mTORC2/Akt signaling [62,238]. Consistently, upregulation of OTUD7B positively correlates with cancer progression and poor prognosis in lung squamous carcinoma and adenocarcinoma [239]. Another DUB, UCH-L1, is highly expressed in neurons and has been implicated in PD and AD [240].

Despite the dramatic advance in understanding the roles and regulations of E3 ubiquitin ligases/DUBs in human diseases, only a few of their inhibitors are clinically used or in clinical trials [241]. In the past five years, a revolutionary technology called proteolysis targeting chimeras (PROTACs) has gained great attention. Mechanically, a PROTAC is a small molecule composed of two parts for binding of a E3 ligase and a specific protein, leading to protein degradation [242]. To date, several E3 ligases have been used for designing PROTAC, including Hrt1, VHL, CRBN, MDM2, DCAF15, RNF114, and IAPs [243]. Recently, two PROTAC molecules, ARV-110 and ARV-471, have entered phase I clinical tri- 
als for prostate cancer and breast cancer, respectively [244]. It is expected that the PROTAC technology will significantly facilitate targeting of the disease-driving proteins, especially the "undruggable" proteins for human diseases treatment in the next decade.

\section{Conclusions}

Since identification of the mTOR kinase in the 1990s, significant progress has been made in the mTOR research field, notably mTORC1 signaling. Many new components and regulators were discovered to make up the delicate mTOR network. Given the essential role of the mTOR pathway in many fundamental biological processes, complete loss of most mTOR components has been proved to be embryonically lethal in mouse, such as mTOR, Raptor, mLST8, Rictor, Sin1, Rheb, and RagA [245]. Therefore, aberrant mTOR signaling in human diseases may be caused by tissue-specific deficiency in these components in terms of their expression, activity, localization, or protein interaction, all of which can be regulated by PTMs. As described in this review, PTMs indeed offer a flexible and precise regulation of the mTOR signaling in response to various external inputs. Moreover, aberrant expression and enzymatic activity of these PTM enzymes are frequently tissue-dependent, which may explain the imbalance of mTOR activity in different diseases.

To date, more than 200 types of PTMs have been identified and play key roles in regulating protein functions in all signaling pathways. However, only a few kinds of PTMs have been validated in a dozen mTOR components and linked to the dysregulation of mTOR signaling. Therefore, identifying functional PTMs on mTOR components would be of great interest in future studies, which may provide more strategies for therapeutically targeting mTOR signaling in clinic.

Author Contributions: Conceptualization, S.Y. and W.G.; writing-original draft, S.Y. and L.L.; writing-review and editing S.Y. and W.G. All authors have read and agreed to the published version of the manuscript.

Funding: This work was supported by the National Cancer Institute, grants number R00CA207867 (W.G.) and Hollings Cancer Center Abney Postdoctoral Fellowship (S.Y.).

Institutional Review Board Statement: Not applicable.

Informed Consent Statement: Not applicable.

Data Availability Statement: No new data were created or analyzed in this study. Data sharing is not applicable to this article.

Conflicts of Interest: The authors declare no conflict of interest.

$\begin{array}{ll}\text { Abbreviations } \\ \text { 4E-BPs } & \text { eukaryotic initiation factor 4E-binding proteins } \\ \text { AMBRA1 } & \text { autophagy and Beclin 1 regulator 1 } \\ \text { AMPK } & \text { AMP-activated protein kinase } \\ \text { ATF4 } & \text { activating transcription factor } 4 \\ \text { ATG13 } & \text { Autophagy-related protein 13 } \\ \text { ATXN3 } & \text { Ataxin-3 } \\ \text { CAD } & \text { carbamoyl-phosphate synthetase 2 } \\ \text { CASTOR1 } & \text { cellular arginine sensor for mTORC1 } \\ \text { CDC25 } & \text { cell division cycle 25 } \\ \text { CHIP } & \text { carboxy-terminus of Hsc70 interacting protein } \\ \text { CRBN } & \text { cereblon } \\ \text { CUL4 } & \text { cullin 4 } \\ \text { DCAF15 } & \text { DDB1- and CUL4-associated factor 15 } \\ \text { DDB1 } & \text { DNA damage-binding protein 1 }\end{array}$




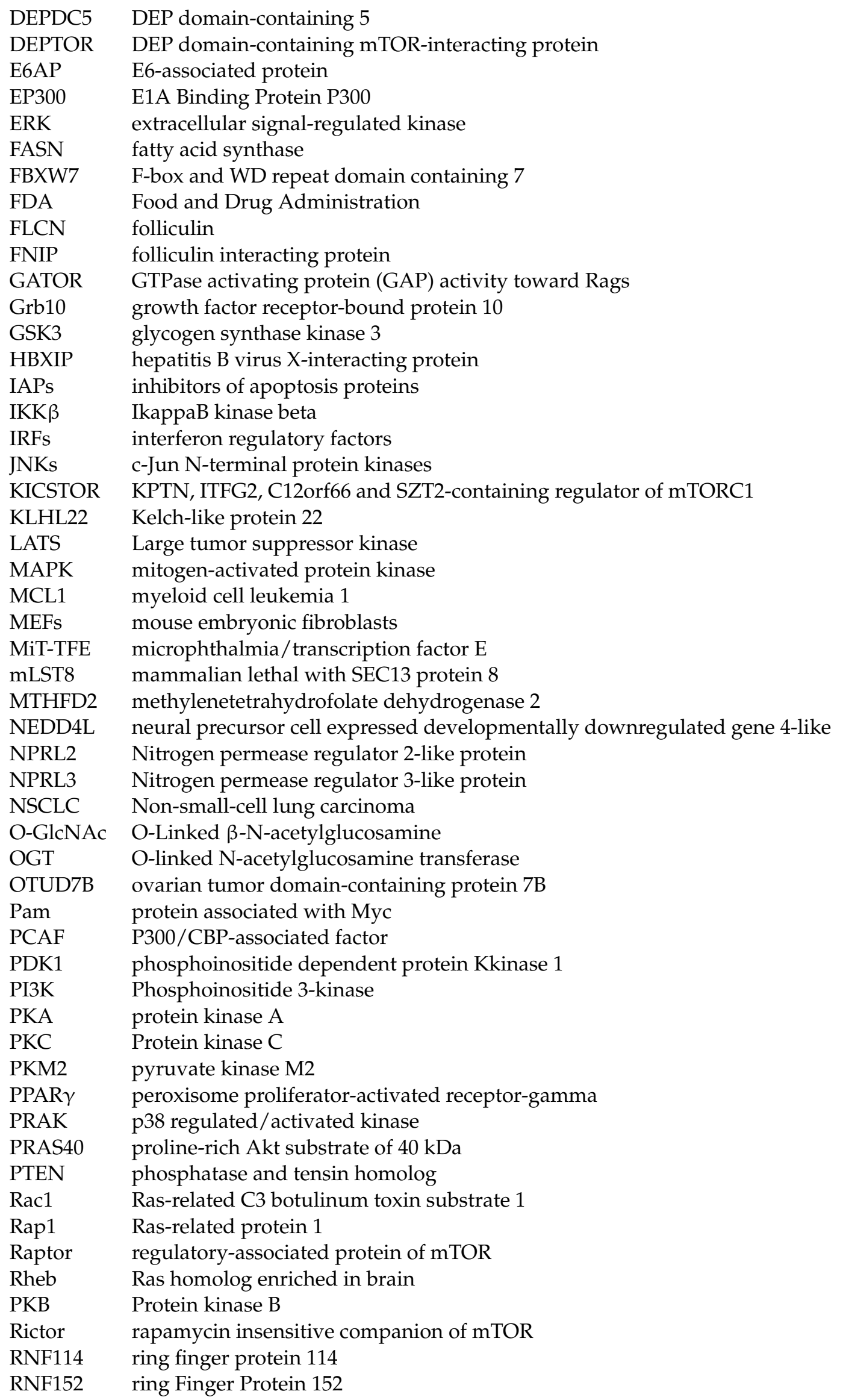




$\begin{array}{ll}\text { RNF186 } & \text { ring finger protein 186 } \\ \text { RSKs } & \text { 90 kDa ribosomal S6 kinases } \\ \text { S6K } & \text { ribosomal protein S6 kinase } \\ \text { SAMTOR } & \text { S-adenosylmethionine sensor upstream of mTORC1 } \\ \text { SGK1 } & \text { serum and glucocorticoid-regulated kinase 1 } \\ \text { Sin1 } & \text { SAPK interacting protein 1 } \\ \text { Skp2 } & \text { S-phase kinase associated protein 2 } \\ \text { SREBP1/2 } & \text { transcriptional factors sterol regulatory element binding protein 1/2 } \\ \text { TFEB } & \text { transcription factor EB } \\ \text { TRAF2 } & \text { tumor necrosis factor receptor-associated factor 2 } \\ \text { TRAF6 } & \text { tumor necrosis factor receptor-associated factor 6 } \\ \text { TRIM31 } & \text { tripartite motif-containing protein 31 } \\ \text { TSC } & \text { Tuberous sclerosis complex } \\ \text { UCH-L1 } & \text { ubiquitin carboxy-terminal hydrolase L1 } \\ \text { ULK1 } & \text { unc-51 like autophagy activating kinase 1 } \\ \text { UVRAG } & \text { UV radiation resistance-associated gene protein } \\ \text { VHL } & \text { Von Hippel-Lindau } \\ \text { WDR24 } & \text { WD repeat domain 24 } \\ \text { WDR59 } & \text { WD repeat domain 59 }\end{array}$

\section{References}

1. Liu, G.Y.; Sabatini, D.M. mTOR at the nexus of nutrition, growth, ageing and disease. Nat. Rev. Mol. Cell Biol. 2020, $21,183-203$. [CrossRef]

2. Mossmann, D.; Park, S.; Hall, M.N. mTOR signalling and cellular metabolism are mutual determinants in cancer. Nat. Rev. Cancer 2018, 18, 744-757. [CrossRef] [PubMed]

3. Saxton, R.A.; Sabatini, D.M. mTOR Signaling in Growth, Metabolism, and Disease. Cell 2017, 169, 361-371. [CrossRef] [PubMed]

4. Hara, K.; Maruki, Y.; Long, X.; Yoshino, K.; Oshiro, N.; Hidayat, S.; Tokunaga, C.; Avruch, J.; Yonezawa, K. Raptor, a binding partner of target of rapamycin (TOR), mediates TOR action. Cell 2002, 110, 177-189. [CrossRef]

5. Kim, D.H.; Sarbassov, D.D.; Ali, S.M.; King, J.E.; Latek, R.R.; Erdjument-Bromage, H.; Tempst, P.; Sabatini, D.M. mTOR interacts with raptor to form a nutrient-sensitive complex that signals to the cell growth machinery. Cell 2002, 110, 163-175. [CrossRef]

6. Sabatini, D.M. mTOR and cancer: Insights into a complex relationship. Nat. Rev. Cancer 2006, 6, 729-734. [CrossRef] [PubMed]

7. Sarbassov, D.D.; Ali, S.M.; Kim, D.H.; Guertin, D.A.; Latek, R.R.; Erdjument-Bromage, H.; Tempst, P.; Sabatini, D.M. Rictor, a novel binding partner of $\mathrm{mTOR}$, defines a rapamycin-insensitive and raptor-independent pathway that regulates the cytoskeleton. Curr. Biol. 2004, 14, 1296-1302. [CrossRef] [PubMed]

8. Yang, H.; Rudge, D.G.; Koos, J.D.; Vaidialingam, B.; Yang, H.J.; Pavletich, N.P. mTOR kinase structure, mechanism and regulation. Nature 2013, 497, 217-223. [CrossRef] [PubMed]

9. Nojima, H.; Tokunaga, C.; Eguchi, S.; Oshiro, N.; Hidayat, S.; Yoshino, K.; Hara, K.; Tanaka, N.; Avruch, J.; Yonezawa, K. The mammalian target of rapamycin (mTOR) partner, raptor, binds the mTOR substrates p70 S6 kinase and 4E-BP1 through their TOR signaling (TOS) motif. J. Biol. Chem. 2003, 278, 15461-15464. [CrossRef] [PubMed]

10. Schalm, S.S.; Fingar, D.C.; Sabatini, D.M.; Blenis, J. TOS motif-mediated raptor binding regulates 4E-BP1 multisite phosphorylation and function. Curr. Biol. 2003, 13, 797-806. [CrossRef]

11. Jacinto, E.; Facchinetti, V.; Liu, D.; Soto, N.; Wei, S.; Jung, S.Y.; Huang, Q.; Qin, J.; Su, B. SIN1/MIP1 maintains rictor-mTOR complex integrity and regulates Akt phosphorylation and substrate specificity. Cell 2006, 127, 125-137. [CrossRef] [PubMed]

12. Peterson, T.R.; Laplante, M.; Thoreen, C.C.; Sancak, Y.; Kang, S.A.; Kuehl, W.M.; Gray, N.S.; Sabatini, D.M. DEPTOR is an mTOR inhibitor frequently overexpressed in multiple myeloma cells and required for their survival. Cell 2009, 137, 873-886. [CrossRef] [PubMed]

13. Wang, X.; Proud, C.G. The mTOR pathway in the control of protein synthesis. Physiology (Bethesda) 2006, 21, 362-369. [CrossRef] [PubMed]

14. Laplante, M.; Sabatini, D.M. An emerging role of mTOR in lipid biosynthesis. Curr. Biol. 2009, 19, R1046-R1052. [CrossRef] [PubMed]

15. Ben-Sahra, I.; Howell, J.J.; Asara, J.M.; Manning, B.D. Stimulation of de novo pyrimidine synthesis by growth signaling through mTOR and S6K1. Science 2013, 339, 1323-1328. [CrossRef] [PubMed]

16. Robitaille, A.M.; Christen, S.; Shimobayashi, M.; Cornu, M.; Fava, L.L.; Moes, S.; Prescianotto-Baschong, C.; Sauer, U.; Jenoe, P.; Hall, M.N. Quantitative phosphoproteomics reveal mTORC1 activates de novo pyrimidine synthesis. Science 2013, 339, 1320-1323. [CrossRef] [PubMed]

17. Ben-Sahra, I.; Hoxhaj, G.; Ricoult, S.J.H.; Asara, J.M.; Manning, B.D. mTORC1 induces purine synthesis through control of the mitochondrial tetrahydrofolate cycle. Science 2016, 351, 728-733. [CrossRef] [PubMed] 
18. Dossou, A.S.; Basu, A. The Emerging Roles of mTORC1 in Macromanaging Autophagy. Cancers 2019, 11, 1422. [CrossRef]

19. Bar-Peled, L.; Schweitzer, L.D.; Zoncu, R.; Sabatini, D.M. Ragulator is a GEF for the rag GTPases that signal amino acid levels to mTORC1. Cell 2012, 150, 1196-1208. [CrossRef] [PubMed]

20. Sancak, Y.; Bar-Peled, L.; Zoncu, R.; Markhard, A.L.; Nada, S.; Sabatini, D.M. Ragulator-Rag complex targets mTORC1 to the lysosomal surface and is necessary for its activation by amino acids. Cell 2010, 141, 290-303. [CrossRef] [PubMed]

21. Tsun, Z.Y.; Bar-Peled, L.; Chantranupong, L.; Zoncu, R.; Wang, T.; Kim, C.; Spooner, E.; Sabatini, D.M. The folliculin tumor suppressor is a GAP for the RagC/D GTPases that signal amino acid levels to mTORC1. Mol. Cell 2013, 52, 495-505. [CrossRef] [PubMed]

22. Sancak, Y.; Peterson, T.R.; Shaul, Y.D.; Lindquist, R.A.; Thoreen, C.C.; Bar-Peled, L.; Sabatini, D.M. The Rag GTPases bind raptor and mediate amino acid signaling to mTORC1. Science 2008, 320, 1496-1501. [CrossRef]

23. Long, X.; Lin, Y.; Ortiz-Vega, S.; Yonezawa, K.; Avruch, J. Rheb binds and regulates the mTOR kinase. Curr. Biol. 2005, 15, 702-713. [CrossRef]

24. Yang, H.; Jiang, X.; Li, B.; Yang, H.J.; Miller, M.; Yang, A.; Dhar, A.; Pavletich, N.P. Mechanisms of mTORC1 activation by RHEB and inhibition by PRAS40. Nature 2017, 552, 368-373. [CrossRef] [PubMed]

25. Manning, B.D.; Tee, A.R.; Logsdon, M.N.; Blenis, J.; Cantley, L.C. Identification of the tuberous sclerosis complex-2 tumor suppressor gene product tuberin as a target of the phosphoinositide 3-kinase/akt pathway. Mol. Cell 2002, 10, 151-162. [CrossRef]

26. Inoki, K.; Li, Y.; Zhu, T.; Wu, J.; Guan, K.L. TSC2 is phosphorylated and inhibited by Akt and suppresses mTOR signalling. Nat. Cell Biol. 2002, 4, 648-657. [CrossRef] [PubMed]

27. Potter, C.J.; Pedraza, L.G.; Xu, T. Akt regulates growth by directly phosphorylating Tsc2. Nat. Cell Biol. 2002, 4, 658-665. [CrossRef] [PubMed]

28. Menon, S.; Dibble, C.C.; Talbott, G.; Hoxhaj, G.; Valvezan, A.J.; Takahashi, H.; Cantley, L.C.; Manning, B.D. Spatial control of the TSC complex integrates insulin and nutrient regulation of mTORC1 at the lysosome. Cell 2014, 156, 771-785. [CrossRef] [PubMed]

29. Bar-Peled, L.; Chantranupong, L.; Cherniack, A.D.; Chen, W.W.; Ottina, K.A.; Grabiner, B.C.; Spear, E.D.; Carter, S.L.; Meyerson, M.; Sabatini, D.M. A Tumor suppressor complex with GAP activity for the Rag GTPases that signal amino acid sufficiency to mTORC1. Science 2013, 340, 1100-1106. [CrossRef] [PubMed]

30. Peng, M.; Yin, N.; Li, M.O. SZT2 dictates GATOR control of mTORC1 signalling. Nature 2017, 543, 433-437. [CrossRef] [PubMed]

31. Wolfson, R.L.; Chantranupong, L.; Wyant, G.A.; Gu, X.; Orozco, J.M.; Shen, K.; Condon, K.J.; Petri, S.; Kedir, J.; Scaria, S.M.; et al. KICSTOR recruits GATOR1 to the lysosome and is necessary for nutrients to regulate mTORC1. Nature 2017, 543, 438-442. [CrossRef]

32. Peng, M.; Yin, N.; Li, M.O. Sestrins function as guanine nucleotide dissociation inhibitors for Rag GTPases to control mTORC1 signaling. Cell 2014, 159, 122-133. [CrossRef] [PubMed]

33. Wolfson, R.L.; Chantranupong, L.; Saxton, R.A.; Shen, K.; Scaria, S.M.; Cantor, J.R.; Sabatini, D.M. Sestrin2 is a leucine sensor for the mTORC1 pathway. Science 2016, 351, 43-48. [CrossRef] [PubMed]

34. Gu, X.; Orozco, J.M.; Saxton, R.A.; Condon, K.J.; Liu, G.Y.; Krawczyk, P.A.; Scaria, S.M.; Harper, J.W.; Gygi, S.P.; Sabatini, D.M. SAMTOR is an S-adenosylmethionine sensor for the mTORC1 pathway. Science 2017, 358, 813-818. [CrossRef] [PubMed]

35. Chantranupong, L.; Scaria, S.M.; Saxton, R.A.; Gygi, M.P.; Shen, K.; Wyant, G.A.; Wang, T.; Harper, J.W.; Gygi, S.P.; Sabatini, D.M. The CASTOR Proteins Are Arginine Sensors for the mTORC1 Pathway. Cell 2016, 165, 153-164. [CrossRef] [PubMed]

36. Wang, S.; Tsun, Z.Y.; Wolfson, R.L.; Shen, K.; Wyant, G.A.; Plovanich, M.E.; Yuan, E.D.; Jones, T.D.; Chantranupong, L.; Comb, W.; et al. Metabolism. Lysosomal amino acid transporter SLC38A9 signals arginine sufficiency to mTORC1. Science 2015, 347, 188-194. [CrossRef] [PubMed]

37. Jacinto, E.; Loewith, R.; Schmidt, A.; Lin, S.; Ruegg, M.A.; Hall, A.; Hall, M.N. Mammalian TOR complex 2 controls the actin cytoskeleton and is rapamycin insensitive. Nat. Cell Biol. 2004, 6, 1122-1128. [CrossRef] [PubMed]

38. Oh, W.J.; Jacinto, E. mTOR complex 2 signaling and functions. Cell Cycle 2011, 10, 2305-2316. [CrossRef] [PubMed]

39. Manning, B.D.; Toker, A. AKT/PKB Signaling: Navigating the Network. Cell 2017, 169, 381-405. [CrossRef]

40. Liu, P.; Gan, W.; Chin, Y.R.; Ogura, K.; Guo, J.; Zhang, J.; Wang, B.; Blenis, J.; Cantley, L.C.; Toker, A.; et al. PtdIns(3,4,5)P3Dependent Activation of the mTORC2 Kinase Complex. Cancer Discov. 2015, 5, 1194-1209. [CrossRef]

41. Saci, A.; Cantley, L.C.; Carpenter, C.L. Rac1 regulates the activity of mTORC1 and mTORC2 and controls cellular size. Mol. Cell 2011, 42, 50-61. [CrossRef]

42. Senoo, H.; Kamimura, Y.; Kimura, R.; Nakajima, A.; Sawai, S.; Sesaki, H.; Iijima, M. Phosphorylated Rho-GDP directly activates mTORC2 kinase towards AKT through dimerization with Ras-GTP to regulate cell migration. Nat. Cell Biol. 2019, 21, 867-878. [CrossRef] [PubMed]

43. Chiang, G.G.; Abraham, R.T. Phosphorylation of mammalian target of rapamycin (mTOR) at Ser-2448 is mediated by p70S6 kinase. J. Biol. Chem. 2005, 280, 25485-25490. [CrossRef]

44. Holz, M.K.; Blenis, J. Identification of S6 kinase 1 as a novel mammalian target of rapamycin (mTOR)-phosphorylating kinase. J. Biol. Chem. 2005, 280, 26089-26093. [CrossRef] [PubMed]

45. Nave, B.T.; Ouwens, M.; Withers, D.J.; Alessi, D.R.; Shepherd, P.R. Mammalian target of rapamycin is a direct target for protein kinase B: Identification of a convergence point for opposing effects of insulin and amino-acid deficiency on protein translation. Biochem. J. 1999, 344 Pt 2, 427-431. [CrossRef] 
46. Sekulic, A.; Hudson, C.C.; Homme, J.L.; Yin, P.; Otterness, D.M.; Karnitz, L.M.; Abraham, R.T. A direct linkage between the phosphoinositide 3-kinase-AKT signaling pathway and the mammalian target of rapamycin in mitogen-stimulated and transformed cells. Cancer Res. 2000, 60, 3504-3513. [PubMed]

47. Cheng, S.W.; Fryer, L.G.; Carling, D.; Shepherd, P.R. Thr2446 is a novel mammalian target of rapamycin (mTOR) phosphorylation site regulated by nutrient status. J. Biol. Chem. 2004, 279, 15719-15722. [CrossRef]

48. Acosta-Jaquez, H.A.; Keller, J.A.; Foster, K.G.; Ekim, B.; Soliman, G.A.; Feener, E.P.; Ballif, B.A.; Fingar, D.C. Site-specific mTOR phosphorylation promotes mTORC1-mediated signaling and cell growth. Mol. Cell. Biol. 2009, 29, 4308-4324. [CrossRef] [PubMed]

49. Peterson, R.T.; Beal, P.A.; Comb, M.J.; Schreiber, S.L. FKBP12-rapamycin-associated protein (FRAP) autophosphorylates at serine 2481 under translationally repressive conditions. J. Biol. Chem. 2000, 275, 7416-7423. [CrossRef]

50. Copp, J.; Manning, G.; Hunter, T. TORC-specific phosphorylation of mammalian target of rapamycin (mTOR): Phospho-Ser2481 is a marker for intact mTOR signaling complex 2. Cancer Res. 2009, 69, 1821-1827. [CrossRef] [PubMed]

51. Soliman, G.A.; Acosta-Jaquez, H.A.; Dunlop, E.A.; Ekim, B.; Maj, N.E.; Tee, A.R.; Fingar, D.C. mTOR Ser-2481 autophosphorylation monitors mTORC-specific catalytic activity and clarifies rapamycin mechanism of action. J. Biol. Chem. 2010, 285, 7866-7879. [CrossRef]

52. Ekim, B.; Magnuson, B.; Acosta-Jaquez, H.A.; Keller, J.A.; Feener, E.P.; Fingar, D.C. mTOR kinase domain phosphorylation promotes mTORC1 signaling, cell growth, and cell cycle progression. Mol. Cell. Biol. 2011, 31, 2787-2801. [CrossRef] [PubMed]

53. Li, X.; Alafuzoff, I.; Soininen, H.; Winblad, B.; Pei, J.J. Levels of mTOR and its downstream targets 4E-BP1, eEF2, and eEF2 kinase in relationships with tau in Alzheimer's disease brain. FEBS J. 2005, 272, 4211-4220. [CrossRef] [PubMed]

54. Lee, H. Phosphorylated mTOR Expression Profiles in Human Normal and Carcinoma Tissues. Dis. Markers 2017, $2017,1397063$. [CrossRef] [PubMed]

55. Mao, J.H.; Kim, I.J.; Wu, D.; Climent, J.; Kang, H.C.; DelRosario, R.; Balmain, A. FBXW7 targets mTOR for degradation and cooperates with PTEN in tumor suppression. Science 2008, 321, 1499-1502. [CrossRef] [PubMed]

56. Xu, Y.; Tian, C.; Sun, J.; Zhang, J.; Ren, K.; Fan, X.Y.; Wang, K.; Wang, H.; Yan, Y.E.; Chen, C.; et al. FBXW7-Induced MTOR Degradation Forces Autophagy to Counteract Persistent Prion Infection. Mol. Neurobiol. 2016, 53, 706-719. [CrossRef]

57. Park, D.; Lee, M.N.; Jeong, H.; Koh, A.; Yang, Y.R.; Suh, P.G.; Ryu, S.H. Parkin ubiquitinates mTOR to regulate mTORC1 activity under mitochondrial stress. Cell Signal. 2014, 26, 2122-2130. [CrossRef] [PubMed]

58. Bruning, U.; Morales-Rodriguez, F.; Kalucka, J.; Goveia, J.; Taverna, F.; Queiroz, K.C.S.; Dubois, C.; Cantelmo, A.R.; Chen, R.; Loroch, S.; et al. Impairment of Angiogenesis by Fatty Acid Synthase Inhibition Involves mTOR Malonylation. Cell Metab. 2018, 28, 866-880.e15. [CrossRef] [PubMed]

59. Kim, D.H.; Sarbassov, D.D.; Ali, S.M.; Latek, R.R.; Guntur, K.V.; Erdjument-Bromage, H.; Tempst, P.; Sabatini, D.M. GbetaL, a positive regulator of the rapamycin-sensitive pathway required for the nutrient-sensitive interaction between raptor and $\mathrm{mTOR}$. Mol. Cell 2003, 11, 895-904. [CrossRef]

60. Guertin, D.A.; Stevens, D.M.; Thoreen, C.C.; Burds, A.A.; Kalaany, N.Y.; Moffat, J.; Brown, M.; Fitzgerald, K.J.; Sabatini, D.M. Ablation in mice of the mTORC components raptor, rictor, or mLST8 reveals that mTORC2 is required for signaling to Akt-FOXO and PKCalpha, but not S6K1. Dev. Cell 2006, 11, 859-871. [CrossRef]

61. Hwang, Y.; Kim, L.C.; Song, W.; Edwards, D.N.; Cook, R.S.; Chen, J. Disruption of the Scaffolding Function of mLST8 Selectively Inhibits mTORC2 Assembly and Function and Suppresses mTORC2-Dependent Tumor Growth In Vivo. Cancer Res. 2019, 79, 3178-3184. [CrossRef]

62. Wang, B.; Jie, Z.; Joo, D.; Ordureau, A.; Liu, P.; Gan, W.; Guo, J.; Zhang, J.; North, B.J.; Dai, X.; et al. TRAF2 and OTUD7B govern a ubiquitin-dependent switch that regulates mTORC2 signalling. Nature 2017, 545, 365-369. [CrossRef] [PubMed]

63. Wang, Z.; Zhong, J.; Inuzuka, H.; Gao, D.; Shaik, S.; Sarkar, F.H.; Wei, W. An evolving role for DEPTOR in tumor development and progression. Neoplasia 2012, 14, 368-375. [CrossRef] [PubMed]

64. Duan, S.; Skaar, J.R.; Kuchay, S.; Toschi, A.; Kanarek, N.; Ben-Neriah, Y.; Pagano, M. mTOR generates an auto-amplification loop by triggering the betaTrCP- and CK1alpha-dependent degradation of DEPTOR. Mol. Cell 2011, 44, 317-324. [CrossRef] [PubMed]

65. Gao, D.; Inuzuka, H.; Tan, M.K.; Fukushima, H.; Locasale, J.W.; Liu, P.; Wan, L.; Zhai, B.; Chin, Y.R.; Shaik, S.; et al. mTOR drives its own activation via SCF(betaTrCP)-dependent degradation of the mTOR inhibitor DEPTOR. Mol. Cell 2011, 44, 290-303. [CrossRef]

66. Zhao, Y.; Xiong, X.; Sun, Y. DEPTOR, an mTOR inhibitor, is a physiological substrate of SCF(betaTrCP) E3 ubiquitin ligase and regulates survival and autophagy. Mol. Cell 2011, 44, 304-316. [CrossRef] [PubMed]

67. Gonzalez-Teran, B.; Lopez, J.A.; Rodriguez, E.; Leiva, L.; Martinez-Martinez, S.; Bernal, J.A.; Jimenez-Borreguero, L.J.; Redondo, J.M.; Vazquez, J.; Sabio, G. p38gamma and delta promote heart hypertrophy by targeting the mTOR-inhibitory protein DEPTOR for degradation. Nat. Commun. 2016, 7, 10477. [CrossRef] [PubMed]

68. Shende, P.; Plaisance, I.; Morandi, C.; Pellieux, C.; Berthonneche, C.; Zorzato, F.; Krishnan, J.; Lerch, R.; Hall, M.N.; Ruegg, M.A.; et al. Cardiac raptor ablation impairs adaptive hypertrophy, alters metabolic gene expression, and causes heart failure in mice. Circulation 2011, 123, 1073-1082. [CrossRef] [PubMed]

69. Lee, P.L.; Tang, Y.; Li, H.; Guertin, D.A. Raptor/mTORC1 loss in adipocytes causes progressive lipodystrophy and fatty liver disease. Mol. Metab. 2016, 5, 422-432. [CrossRef] [PubMed] 
70. Bentzinger, C.F.; Romanino, K.; Cloetta, D.; Lin, S.; Mascarenhas, J.B.; Oliveri, F.; Xia, J.; Casanova, E.; Costa, C.F.; Brink, M.; et al. Skeletal muscle-specific ablation of raptor, but not of rictor, causes metabolic changes and results in muscle dystrophy. Cell Metab. 2008, 8, 411-424. [CrossRef]

71. Umemura, A.; Park, E.J.; Taniguchi, K.; Lee, J.H.; Shalapour, S.; Valasek, M.A.; Aghajan, M.; Nakagawa, H.; Seki, E.; Hall, M.N.; et al. Liver damage, inflammation, and enhanced tumorigenesis after persistent mTORC1 inhibition. Cell Metab. 2014, 20, 133-144. [CrossRef] [PubMed]

72. Foster, K.G.; Acosta-Jaquez, H.A.; Romeo, Y.; Ekim, B.; Soliman, G.A.; Carriere, A.; Roux, P.P.; Ballif, B.A.; Fingar, D.C. Regulation of mTOR complex 1 (mTORC1) by raptor Ser863 and multisite phosphorylation. J. Biol. Chem. 2010, 285, 80-94. [CrossRef]

73. Fujishita, T.; Aoki, M.; Taketo, M.M. JNK signaling promotes intestinal tumorigenesis through activation of mTOR complex 1 in Apc(Delta716) mice. Gastroenterology 2011, 140, 1556-1563.e6. [CrossRef] [PubMed]

74. Kwak, D.; Choi, S.; Jeong, H.; Jang, J.H.; Lee, Y.; Jeon, H.; Lee, M.N.; Noh, J.; Cho, K.; Yoo, J.S.; et al. Osmotic stress regulates mammalian target of rapamycin (mTOR) complex 1 via c-Jun N-terminal Kinase (JNK)-mediated Raptor protein phosphorylation. J. Biol. Chem. 2012, 287, 18398-18407. [CrossRef] [PubMed]

75. Ramirez-Valle, F.; Badura, M.L.; Braunstein, S.; Narasimhan, M.; Schneider, R.J. Mitotic raptor promotes mTORC1 activity, $\mathrm{G}(2) / \mathrm{M}$ cell cycle progression, and internal ribosome entry site-mediated mRNA translation. Mol. Cell. Biol. 2010, 30, 3151-3164. [CrossRef] [PubMed]

76. Gwinn, D.M.; Asara, J.M.; Shaw, R.J. Raptor is phosphorylated by cdc2 during mitosis. PLoS ONE 2010, 5, e9197. [CrossRef] [PubMed]

77. Carriere, A.; Cargnello, M.; Julien, L.A.; Gao, H.; Bonneil, E.; Thibault, P.; Roux, P.P. Oncogenic MAPK signaling stimulates mTORC1 activity by promoting RSK-mediated raptor phosphorylation. Curr. Biol. 2008, 18, 1269-1277. [CrossRef] [PubMed]

78. Gwinn, D.M.; Shackelford, D.B.; Egan, D.F.; Mihaylova, M.M.; Mery, A.; Vasquez, D.S.; Turk, B.E.; Shaw, R.J. AMPK phosphorylation of raptor mediates a metabolic checkpoint. Mol. Cell 2008, 30, 214-226. [CrossRef] [PubMed]

79. Gan, W.; Dai, X.; Dai, X.; Xie, J.; Yin, S.; Zhu, J.; Wang, C.; Liu, Y.; Guo, J.; Wang, M.; et al. LATS suppresses mTORC1 activity to directly coordinate Hippo and mTORC1 pathways in growth control. Nat. Cell Biol. 2020, 22, 246-256. [CrossRef] [PubMed]

80. Ghosh, P.; Wu, M.; Zhang, H.; Sun, H. mTORC1 signaling requires proteasomal function and the involvement of CUL4-DDB1 ubiquitin E3 ligase. Cell Cycle 2008, 7, 373-381. [CrossRef] [PubMed]

81. Hussain, S.; Feldman, A.L.; Das, C.; Ziesmer, S.C.; Ansell, S.M.; Galardy, P.J. Ubiquitin hydrolase UCH-L1 destabilizes mTOR complex 1 by antagonizing DDB1-CUL4-mediated ubiquitination of raptor. Mol. Cell. Biol. 2013, 33, 1188-1197. [CrossRef]

82. Son, S.M.; Park, S.J.; Stamatakou, E.; Vicinanza, M.; Menzies, F.M.; Rubinsztein, D.C. Leucine regulates autophagy via acetylation of the mTORC1 component raptor. Nat. Commun. 2020, 11, 3148. [CrossRef] [PubMed]

83. Sancak, Y.; Thoreen, C.C.; Peterson, T.R.; Lindquist, R.A.; Kang, S.A.; Spooner, E.; Carr, S.A.; Sabatini, D.M. PRAS40 is an insulin-regulated inhibitor of the mTORC1 protein kinase. Mol. Cell 2007, 25, 903-915. [CrossRef] [PubMed]

84. Thedieck, K.; Polak, P.; Kim, M.L.; Molle, K.D.; Cohen, A.; Jeno, P.; Arrieumerlou, C.; Hall, M.N. PRAS40 and PRR5-like protein are new mTOR interactors that regulate apoptosis. PLoS ONE 2007, 2, e1217. [CrossRef] [PubMed]

85. Vander Haar, E.; Lee, S.I.; Bandhakavi, S.; Griffin, T.J.; Kim, D.H. Insulin signalling to mTOR mediated by the Akt/PKB substrate PRAS40. Nat. Cell Biol. 2007, 9, 316-323. [CrossRef]

86. Lv, D.; Guo, L.; Zhang, T.; Huang, L. PRAS40 signaling in tumor. Oncotarget 2017, 8, 69076-69085. [CrossRef]

87. Madhunapantula, S.V.; Sharma, A.; Robertson, G.P. PRAS40 deregulates apoptosis in malignant melanoma. Cancer Res. 2007, 67, 3626-3636. [CrossRef] [PubMed]

88. Shipitsin, M.; Small, C.; Giladi, E.; Siddiqui, S.; Choudhury, S.; Hussain, S.; Huang, Y.E.; Chang, H.; Rimm, D.L.; Berman, D.M.; et al. Automated quantitative multiplex immunofluorescence in situ imaging identifies phospho-S6 and phospho-PRAS40 as predictive protein biomarkers for prostate cancer lethality. Proteome Sci. 2014, 12, 40. [CrossRef] [PubMed]

89. Lu, Y.Z.; Deng, A.M.; Li, L.H.; Liu, G.Y.; Wu, G.Y. Prognostic role of phospho-PRAS40 (Thr246) expression in gastric cancer. Arch. Med. Sci. 2014, 10, 149-153. [CrossRef] [PubMed]

90. Vincent, E.E.; Elder, D.J.; Thomas, E.C.; Phillips, L.; Morgan, C.; Pawade, J.; Sohail, M.; May, M.T.; Hetzel, M.R.; Tavare, J.M. Akt phosphorylation on Thr308 but not on Ser473 correlates with Akt protein kinase activity in human non-small cell lung cancer. Br. J. Cancer 2011, 104, 1755-1761. [CrossRef]

91. Jazet, I.M.; Schaart, G.; Gastaldelli, A.; Ferrannini, E.; Hesselink, M.K.; Schrauwen, P.; Romijn, J.A.; Maassen, J.A.; Pijl, H.; Ouwens, D.M.; et al. Loss of 50\% of excess weight using a very low energy diet improves insulin-stimulated glucose disposal and skeletal muscle insulin signalling in obese insulin-treated type 2 diabetic patients. Diabetologia 2008, 51, 309-319. [CrossRef] [PubMed]

92. Zhou, Q.; Tang, S.; Zhang, X.; Chen, L. Targeting PRAS40: A novel therapeutic strategy for human diseases. J. Drug Target. 2021, 1-44. [CrossRef] [PubMed]

93. Dibble, C.C.; Elis, W.; Menon, S.; Qin, W.; Klekota, J.; Asara, J.M.; Finan, P.M.; Kwiatkowski, D.J.; Murphy, L.O.; Manning, B.D. TBC1D7 is a third subunit of the TSC1-TSC2 complex upstream of mTORC1. Mol. Cell 2012, 47, 535-546. [CrossRef] [PubMed]

94. Orlova, K.A.; Crino, P.B. The tuberous sclerosis complex. Ann. N. Y. Acad. Sci. 2010, 1184, 87-105. [CrossRef] [PubMed]

95. Manning, B.D.; Cantley, L.C. Rheb fills a GAP between TSC and TOR. Trends Biochem. Sci. 2003, 28, 573-576. [CrossRef] [PubMed]

96. Ma, L.; Chen, Z.; Erdjument-Bromage, H.; Tempst, P.; Pandolfi, P.P. Phosphorylation and functional inactivation of TSC2 by Erk implications for tuberous sclerosis and cancer pathogenesis. Cell 2005, 121, 179-193. [CrossRef] [PubMed] 
97. Ballif, B.A.; Roux, P.P.; Gerber, S.A.; MacKeigan, J.P.; Blenis, J.; Gygi, S.P. Quantitative phosphorylation profiling of the ERK/p90 ribosomal S6 kinase-signaling cassette and its targets, the tuberous sclerosis tumor suppressors. Proc. Natl. Acad. Sci. USA 2005, 102, 667-672. [CrossRef] [PubMed]

98. Roux, P.P.; Ballif, B.A.; Anjum, R.; Gygi, S.P.; Blenis, J. Tumor-promoting phorbol esters and activated Ras inactivate the tuberous sclerosis tumor suppressor complex via p90 ribosomal 66 kinase. Proc. Natl. Acad. Sci. USA 2004, 101, 13489-13494. [CrossRef] [PubMed]

99. Inoki, K.; Zhu, T.; Guan, K.L. TSC2 mediates cellular energy response to control cell growth and survival. Cell 2003, 115, 577-590. [CrossRef]

100. Lee, D.F.; Kuo, H.P.; Chen, C.T.; Hsu, J.M.; Chou, C.K.; Wei, Y.; Sun, H.L.; Li, L.Y.; Ping, B.; Huang, W.C.; et al. IKK beta suppression of TSC1 links inflammation and tumor angiogenesis via the mTOR pathway. Cell 2007, 130, 440-455. [CrossRef]

101. Guo, P.; Ma, X.; Zhao, W.; Huai, W.; Li, T.; Qiu, Y.; Zhang, Y.; Han, L. TRIM31 is upregulated in hepatocellular carcinoma and promotes disease progression by inducing ubiquitination of TSC1-TSC2 complex. Oncogene 2018, 37, 478-488. [CrossRef]

102. Han, S.; Witt, R.M.; Santos, T.M.; Polizzano, C.; Sabatini, B.L.; Ramesh, V. Pam (Protein associated with Myc) functions as an E3 ubiquitin ligase and regulates TSC/mTOR signaling. Cell Signal. 2008, 20, 1084-1091. [CrossRef] [PubMed]

103. Zheng, L.; Ding, H.; Lu, Z.; Li, Y.; Pan, Y.; Ning, T.; Ke, Y. E3 ubiquitin ligase E6AP-mediated TSC2 turnover in the presence and absence of HPV16 E6. Genes Cells 2008, 13, 285-294. [CrossRef] [PubMed]

104. Hu, J.; Zacharek, S.; He, Y.J.; Lee, H.; Shumway, S.; Duronio, R.J.; Xiong, Y. WD40 protein FBW5 promotes ubiquitination of tumor suppressor TSC2 by DDB1-CUL4-ROC1 ligase. Genes Dev. 2008, 22, 866-871. [CrossRef] [PubMed]

105. Clark, G.J.; Kinch, M.S.; Rogers-Graham, K.; Sebti, S.M.; Hamilton, A.D.; Der, C.J. The Ras-related protein Rheb is farnesylated and antagonizes Ras signaling and transformation. J. Biol. Chem. 1997, 272, 10608-10615. [CrossRef] [PubMed]

106. Takahashi, K.; Nakagawa, M.; Young, S.G.; Yamanaka, S. Differential membrane localization of ERas and Rheb, two Ras-related proteins involved in the phosphatidylinositol 3-kinase/mTOR pathway. J. Biol. Chem. 2005, 280, 32768-32774. [CrossRef] [PubMed]

107. Zheng, M.; Wang, Y.H.; Wu, X.N.; Wu, S.Q.; Lu, B.J.; Dong, M.Q.; Zhang, H.; Sun, P.; Lin, S.C.; Guan, K.L.; et al. Inactivation of Rheb by PRAK-mediated phosphorylation is essential for energy-depletion-induced suppression of mTORC1. Nat. Cell Biol. 2011, 13, 263-272. [CrossRef] [PubMed]

108. Deng, L.; Chen, L.; Zhao, L.; Xu, Y.; Peng, X.; Wang, X.; Ding, L.; Jin, J.; Teng, H.; Wang, Y.; et al. Ubiquitination of Rheb governs growth factor-induced mTORC1 activation. Cell Res. 2019, 29, 136-150. [CrossRef] [PubMed]

109. Yao, Y.; Hong, S.; Ikeda, T.; Mori, H.; MacDougald, O.A.; Nada, S.; Okada, M.; Inoki, K. Amino Acids Enhance Polyubiquitination of Rheb and Its Binding to mTORC1 by Blocking Lysosomal ATXN3 Deubiquitinase Activity. Mol. Cell 2020, 80, 437-451.e6. [CrossRef] [PubMed]

110. Mavrakis, K.J.; Zhu, H.; Silva, R.L.; Mills, J.R.; Teruya-Feldstein, J.; Lowe, S.W.; Tam, W.; Pelletier, J.; Wendel, H.G. Tumorigenic activity and therapeutic inhibition of Rheb GTPase. Genes Dev. 2008, 22, 2178-2188. [CrossRef]

111. Potheraveedu, V.N.; Schopel, M.; Stoll, R.; Heumann, R. Rheb in neuronal degeneration, regeneration, and connectivity. Biol. Chem. 2017, 398, 589-606. [CrossRef] [PubMed]

112. Okosun, J.; Wolfson, R.L.; Wang, J.; Araf, S.; Wilkins, L.; Castellano, B.M.; Escudero-Ibarz, L.; Al Seraihi, A.F.; Richter, J.; Bernhart, S.H.; et al. Recurrent mTORC1-activating RRAGC mutations in follicular lymphoma. Nat. Genet 2016, 48, 183-188. [CrossRef] [PubMed]

113. Long, P.A.; Zimmermann, M.T.; Kim, M.; Evans, J.M.; Xu, X.; Olson, T.M. De novo RRAGC mutation activates mTORC1 signaling in syndromic fetal dilated cardiomyopathy. Hum. Genet. 2016, 135, 909-917. [CrossRef] [PubMed]

114. Deng, L.; Jiang, C.; Chen, L.; Jin, J.; Wei, J.; Zhao, L.; Chen, M.; Pan, W.; Xu, Y.; Chu, H.; et al. The ubiquitination of rag A GTPase by RNF152 negatively regulates mTORC1 activation. Mol. Cell 2015, 58, 804-818. [CrossRef] [PubMed]

115. Jin, G.; Lee, S.W.; Zhang, X.; Cai, Z.; Gao, Y.; Chou, P.C.; Rezaeian, A.H.; Han, F.; Wang, C.Y.; Yao, J.C.; et al. Skp2-Mediated RagA Ubiquitination Elicits a Negative Feedback to Prevent Amino-Acid-Dependent mTORC1 Hyperactivation by Recruiting GATOR1. Mol. Cell 2015, 58, 989-1000. [CrossRef]

116. Yang, G.; Humphrey, S.J.; Murashige, D.S.; Francis, D.; Wang, Q.P.; Cooke, K.C.; Neely, G.G.; James, D.E. RagC phosphorylation autoregulates mTOR complex 1. EMBO J. 2019, 38, e99548. [CrossRef]

117. Nada, S.; Hondo, A.; Kasai, A.; Koike, M.; Saito, K.; Uchiyama, Y.; Okada, M. The novel lipid raft adaptor p18 controls endosome dynamics by anchoring the MEK-ERK pathway to late endosomes. EMBO J. 2009, 28, 477-489. [CrossRef]

118. Sun, J.; Liu, Y.; Jia, Y.; Hao, X.; Lin, W.J.; Tran, J.; Lynch, G.; Baudry, M.; Bi, X. UBE3A-mediated p18/LAMTOR1 ubiquitination and degradation regulate mTORC1 activity and synaptic plasticity. Elife 2018, 7, e37993. [CrossRef] [PubMed]

119. Williams, C.A.; Zori, R.T.; Stone, J.W.; Gray, B.A.; Cantu, E.S.; Ostrer, H. Maternal origin of 15q11-13 deletions in Angelman syndrome suggests a role for genomic imprinting. Am. J. Med. Genet. 1990, 35, 350-353. [CrossRef]

120. Cook, E.H., Jr.; Lindgren, V.; Leventhal, B.L.; Courchesne, R.; Lincoln, A.; Shulman, C.; Lord, C.; Courchesne, E. Autism or atypical autism in maternally but not paternally derived proximal 15q duplication. Am. J. Hum. Genet. 1997, 60, 928-934. [PubMed]

121. Rasheed, N.; Lima, T.B.; Mercaldi, G.F.; Nascimento, A.F.Z.; Silva, A.L.S.; Righetto, G.L.; Bar-Peled, L.; Shen, K.; Sabatini, D.M.; Gozzo, F.C.; et al. C7orf59/LAMTOR4 phosphorylation and structural flexibility modulate Ragulator assembly. FEBS Open Bio 2019, 9, 1589-1602. [CrossRef] 
122. Chen, J.; Ou, Y.; Yang, Y.; Li, W.; Xu, Y.; Xie, Y.; Liu, Y. KLHL22 activates amino-acid-dependent mTORC1 signalling to promote tumorigenesis and ageing. Nature 2018, 557, 585-589. [CrossRef] [PubMed]

123. Padi, S.K.R.; Singh, N.; Bearss, J.J.; Olive, V.; Song, J.H.; Cardo-Vila, M.; Kraft, A.S.; Okumura, K. Phosphorylation of DEPDC5, a component of the GATOR1 complex, releases inhibition of mTORC1 and promotes tumor growth. Proc. Natl. Acad. Sci. USA 2019, 116, 20505-20510. [CrossRef] [PubMed]

124. Baldassari, S.; Picard, F.; Verbeek, N.E.; van Kempen, M.; Brilstra, E.H.; Lesca, G.; Conti, V.; Guerrini, R.; Bisulli, F.; Licchetta, L.; et al. The landscape of epilepsy-related GATOR1 variants. Genet. Med. 2019, 21, 398-408. [CrossRef] [PubMed]

125. Basel-Vanagaite, L.; Hershkovitz, T.; Heyman, E.; Raspall-Chaure, M.; Kakar, N.; Smirin-Yosef, P.; Vila-Pueyo, M.; Kornreich, L.; Thiele, H.; Bode, H.; et al. Biallelic SZT2 mutations cause infantile encephalopathy with epilepsy and dysmorphic corpus callosum. Am. J. Hum. Genet. 2013, 93, 524-529. [CrossRef] [PubMed]

126. Nickerson, M.L.; Warren, M.B.; Toro, J.R.; Matrosova, V.; Glenn, G.; Turner, M.L.; Duray, P.; Merino, M.; Choyke, P.; Pavlovich, C.P.; et al. Mutations in a novel gene lead to kidney tumors, lung wall defects, and benign tumors of the hair follicle in patients with the Birt-Hogg-Dube syndrome. Cancer Cell 2002, 2, 157-164. [CrossRef]

127. Hasumi, Y.; Baba, M.; Hasumi, H.; Huang, Y.; Lang, M.; Reindorf, R.; Oh, H.B.; Sciarretta, S.; Nagashima, K.; Haines, D.C.; et al. Folliculin (Flcn) inactivation leads to murine cardiac hypertrophy through mTORC1 deregulation. Hum. Mol. Genet. 2014, 23, 5706-5719. [CrossRef] [PubMed]

128. Yu, Y.; Yoon, S.O.; Poulogiannis, G.; Yang, Q.; Ma, X.M.; Villen, J.; Kubica, N.; Hoffman, G.R.; Cantley, L.C.; Gygi, S.P.; et al. Phosphoproteomic analysis identifies Grb10 as an mTORC1 substrate that negatively regulates insulin signaling. Science 2011, 332, 1322-1326. [CrossRef]

129. Dunlop, E.A.; Seifan, S.; Claessens, T.; Behrends, C.; Kamps, M.A.; Rozycka, E.; Kemp, A.J.; Nookala, R.K.; Blenis, J.; Coull, B.J.; et al. FLCN, a novel autophagy component, interacts with GABARAP and is regulated by ULK1 phosphorylation. Autophagy 2014, 10, 1749-1760. [CrossRef]

130. Piao, X.; Kobayashi, T.; Wang, L.; Shiono, M.; Takagi, Y.; Sun, G.; Abe, M.; Hagiwara, Y.; Zhang, D.; Okimoto, K.; et al. Regulation of folliculin (the BHD gene product) phosphorylation by Tsc2-mTOR pathway. Biochem. Biophys. Res. Commun. 2009, 389, 16-21. [CrossRef]

131. Wagner, S.A.; Beli, P.; Weinert, B.T.; Nielsen, M.L.; Cox, J.; Mann, M.; Choudhary, C. A proteome-wide, quantitative survey of in vivo ubiquitylation sites reveals widespread regulatory roles. Mol. Cell. Proteom. 2011, 10, M111.013284. [CrossRef]

132. Danielsen, J.M.; Sylvestersen, K.B.; Bekker-Jensen, S.; Szklarczyk, D.; Poulsen, J.W.; Horn, H.; Jensen, L.J.; Mailand, N.; Nielsen, M.L. Mass spectrometric analysis of lysine ubiquitylation reveals promiscuity at site level. Mol. Cell. Proteom. 2011, 10, M110.003590. [CrossRef]

133. Takahara, T.; Amemiya, Y.; Sugiyama, R.; Maki, M.; Shibata, H. Amino acid-dependent control of mTORC1 signaling: A variety of regulatory modes. J. Biomed. Sci. 2020, 27, 87. [CrossRef] [PubMed]

134. Kim, H.; Jeon, B.T.; Kim, I.M.; Bennett, S.J.; Lorch, C.M.; Viana, M.P.; Myers, J.F.; Trupp, C.J.; Whipps, Z.T.; Kundu, M.; et al Sestrin2 Phosphorylation by ULK1 Induces Autophagic Degradation of Mitochondria Damaged by Copper-Induced Oxidative Stress. Int. J. Mol. Sci. 2020, 21, 6130. [CrossRef] [PubMed]

135. Kimball, S.R.; Gordon, B.S.; Moyer, J.E.; Dennis, M.D.; Jefferson, L.S. Leucine induced dephosphorylation of Sestrin2 promotes mTORC1 activation. Cell Signal. 2016, 28, 896-906. [CrossRef] [PubMed]

136. Lear, T.B.; Lockwood, K.C.; Ouyang, Y.; Evankovich, J.W.; Larsen, M.B.; Lin, B.; Liu, Y.; Chen, B.B. The RING-type E3 ligase RNF186 ubiquitinates Sestrin-2 and thereby controls nutrient sensing. J. Biol. Chem. 2019, 294, 16527-16534. [CrossRef] [PubMed]

137. Beaudoin, M.; Goyette, P.; Boucher, G.; Lo, K.S.; Rivas, M.A.; Stevens, C.; Alikashani, A.; Ladouceur, M.; Ellinghaus, D.; Torkvist, L.; et al. Deep resequencing of GWAS loci identifies rare variants in CARD9, IL23R and RNF186 that are associated with ulcerative colitis. PLoS Genet. 2013, 9, e1003723. [CrossRef] [PubMed]

138. Pasha, M.; Eid, A.H.; Eid, A.A.; Gorin, Y.; Munusamy, S. Sestrin2 as a Novel Biomarker and Therapeutic Target for Various Diseases. Oxid. Med. Cell Longev. 2017, 2017, 3296294. [CrossRef] [PubMed]

139. Magnuson, B.; Ekim, B.; Fingar, D.C. Regulation and function of ribosomal protein S6 kinase (S6K) within mTOR signalling networks. Biochem. J. 2012, 441, 1-21. [CrossRef] [PubMed]

140. Pullen, N.; Thomas, G. The modular phosphorylation and activation of p70s6k. FEBS Lett. 1997, 410, 78-82. [CrossRef]

141. Burnett, P.E.; Barrow, R.K.; Cohen, N.A.; Snyder, S.H.; Sabatini, D.M. RAFT1 phosphorylation of the translational regulators p70 S6 kinase and 4E-BP1. Proc. Natl. Acad. Sci. USA 1998, 95, 1432-1437. [CrossRef] [PubMed]

142. Pullen, N.; Dennis, P.B.; Andjelkovic, M.; Dufner, A.; Kozma, S.C.; Hemmings, B.A.; Thomas, G. Phosphorylation and activation of p70s6k by PDK1. Science 1998, 279, 707-710. [CrossRef] [PubMed]

143. Alessi, D.R.; Kozlowski, M.T.; Weng, Q.P.; Morrice, N.; Avruch, J. 3-Phosphoinositide-dependent protein kinase 1 (PDK1) phosphorylates and activates the p70 S6 kinase in vivo and in vitro. Curr. Biol. 1998, 8, 69-81. [CrossRef]

144. Weng, Q.P.; Kozlowski, M.; Belham, C.; Zhang, A.; Comb, M.J.; Avruch, J. Regulation of the p70 S6 kinase by phosphorylation in vivo. Analysis using site-specific anti-phosphopeptide antibodies. J. Biol. Chem. 1998, 273, 16621-16629. [CrossRef] [PubMed]

145. Hong, S.; Zhao, B.; Lombard, D.B.; Fingar, D.C.; Inoki, K. Cross-talk between sirtuin and mammalian target of rapamycin complex 1 (mTORC1) signaling in the regulation of S6 kinase 1 (S6K1) phosphorylation. J. Biol. Chem. 2014, 289, 13132-13141. [CrossRef]

146. Panasyuk, G.; Nemazanyy, I.; Filonenko, V.; Gout, I. Ribosomal protein S6 kinase 1 interacts with and is ubiquitinated by ubiquitin ligase ROC1. Biochem. Biophys. Res. Commun. 2008, 369, 339-343. [CrossRef] 
147. Kim, J.; Kundu, M.; Viollet, B.; Guan, K.L. AMPK and mTOR regulate autophagy through direct phosphorylation of Ulk1. Nat. Cell Biol. 2011, 13, 132-141. [CrossRef]

148. Pyo, K.E.; Kim, C.R.; Lee, M.; Kim, J.S.; Kim, K.I.; Baek, S.H. ULK1 O-GlcNAcylation Is Crucial for Activating VPS34 via ATG14L during Autophagy Initiation. Cell Rep. 2018, 25, 2878-2890.e4. [CrossRef] [PubMed]

149. Lin, S.Y.; Li, T.Y.; Liu, Q.; Zhang, C.; Li, X.; Chen, Y.; Zhang, S.M.; Lian, G.; Liu, Q.; Ruan, K.; et al. GSK3-TIP60-ULK1 signaling pathway links growth factor deprivation to autophagy. Science 2012, 336, 477-481. [CrossRef]

150. Nazio, F.; Strappazzon, F.; Antonioli, M.; Bielli, P.; Cianfanelli, V.; Bordi, M.; Gretzmeier, C.; Dengjel, J.; Piacentini, M.; Fimia, G.M.; et al. mTOR inhibits autophagy by controlling ULK1 ubiquitylation, self-association and function through AMBRA1 and TRAF6. Nat. Cell Biol. 2013, 15, 406-416. [CrossRef]

151. Kabir, N.N.; Kazi, J.U. Grb10 is a dual regulator of receptor tyrosine kinase signaling. Mol. Biol. Rep. 2014, 41, 1985-1992. [CrossRef] [PubMed]

152. Glidden, E.J.; Gray, L.G.; Vemuru, S.; Li, D.; Harris, T.E.; Mayo, M.W. Multiple site acetylation of Rictor stimulates mammalian target of rapamycin complex 2 (mTORC2)-dependent phosphorylation of Akt protein. J. Biol. Chem. 2012, 287, 581-588. [CrossRef] [PubMed]

153. Koo, J.; Wu, X.; Mao, Z.; Khuri, F.R.; Sun, S.Y. Rictor Undergoes Glycogen Synthase Kinase 3 (GSK3)-dependent, FBXW7-mediated Ubiquitination and Proteasomal Degradation. J. Biol. Chem. 2015, 290, 14120-14129. [CrossRef] [PubMed]

154. Gkountakos, A.; Pilotto, S.; Mafficini, A.; Vicentini, C.; Simbolo, M.; Milella, M.; Tortora, G.; Scarpa, A.; Bria, E.; Corbo, V. Unmasking the impact of Rictor in cancer: Novel insights of mTORC2 complex. Carcinogenesis 2018, 39, 971-980. [CrossRef]

155. Chen, C.H.; Shaikenov, T.; Peterson, T.R.; Aimbetov, R.; Bissenbaev, A.K.; Lee, S.W.; Wu, J.; Lin, H.K.; Sarbassov dos, D. ER stress inhibits mTORC2 and Akt signaling through GSK-3beta-mediated phosphorylation of rictor. Sci. Signal. 2011, 4, ra10. [CrossRef]

156. Julien, L.A.; Carriere, A.; Moreau, J.; Roux, P.P. mTORC1-activated S6K1 phosphorylates Rictor on threonine 1135 and regulates mTORC2 signaling. Mol. Cell. Biol. 2010, 30, 908-921. [CrossRef] [PubMed]

157. Lee, H.K.; Kwon, B.; Lemere, C.A.; de la Monte, S.; Itamura, K.; Ha, A.Y.; Querfurth, H.W. mTORC2 (Rictor) in Alzheimer's Disease and Reversal of Amyloid-beta Expression-Induced Insulin Resistance and Toxicity in Rat Primary Cortical Neurons. J. Alzheimer's Dis. 2017, 56, 1015-1036. [CrossRef] [PubMed]

158. Yang, Q.; Inoki, K.; Ikenoue, T.; Guan, K.L. Identification of Sin1 as an essential TORC2 component required for complex formation and kinase activity. Genes Dev. 2006, 20, 2820-2832. [CrossRef] [PubMed]

159. Wang, D.; Wu, P.; Wang, H.; Zhu, L.; Zhao, W.; Lu, Y. SIN1 promotes the proliferation and migration of breast cancer cells by Akt activation. Biosci. Rep. 2016, 36, e00424. [CrossRef]

160. Xu, J.; Li, X.; Yang, H.; Chang, R.; Kong, C.; Yang, L. SIN1 promotes invasion and metastasis of hepatocellular carcinoma by facilitating epithelial-mesenchymal transition. Cancer 2013, 119, 2247-2257. [CrossRef] [PubMed]

161. Liu, P.; Gan, W.; Inuzuka, H.; Lazorchak, A.S.; Gao, D.; Arojo, O.; Liu, D.; Wan, L.; Zhai, B.; Yu, Y.; et al. Sin1 phosphorylation impairs mTORC2 complex integrity and inhibits downstream Akt signalling to suppress tumorigenesis. Nat. Cell Biol. 2013, 15, 1340-1350. [CrossRef] [PubMed]

162. Yang, G.; Murashige, D.S.; Humphrey, S.J.; James, D.E. A Positive Feedback Loop between Akt and mTORC2 via SIN1 Phosphorylation. Cell Rep. 2015, 12, 937-943. [CrossRef]

163. Cui, B.; Gong, L.; Chen, M.; Zhang, Y.; Yuan, H.; Qin, J.; Gao, D. CUL5-SOCS6 complex regulates mTORC2 function by targeting Sin1 for degradation. Cell Discov. 2019, 5, 52. [CrossRef] [PubMed]

164. Fruman, D.A.; Chiu, H.; Hopkins, B.D.; Bagrodia, S.; Cantley, L.C.; Abraham, R.T. The PI3K Pathway in Human Disease. Cell 2017, 170, 605-635. [CrossRef] [PubMed]

165. Fox, M.; Mott, H.R.; Owen, D. Class IA PI3K regulatory subunits: p110-independent roles and structures. Biochem. Soc. Trans. 2020, 48, 1397-1417. [CrossRef] [PubMed]

166. Burke, J.E. Structural Basis for Regulation of Phosphoinositide Kinases and Their Involvement in Human Disease. Mol. Cell 2018, 71, 653-673. [CrossRef] [PubMed]

167. Leslie, N.R.; Kriplani, N.; Hermida, M.A.; Alvarez-Garcia, V.; Wise, H.M. The PTEN protein: Cellular localization and posttranslational regulation. Biochem. Soc. Trans. 2016, 44, 273-278. [CrossRef] [PubMed]

168. Wang, X.; Jiang, X. Post-translational regulation of PTEN. Oncogene 2008, 27, 5454-5463. [CrossRef] [PubMed]

169. Cai, W.; Andres, D.A. mTORC2 is required for rit-mediated oxidative stress resistance. PLoS ONE 2014, 9, e115602. [CrossRef]

170. Kovalski, J.R.; Bhaduri, A.; Zehnder, A.M.; Neela, P.H.; Che, Y.; Wozniak, G.G.; Khavari, P.A. The Functional Proximal Proteome of Oncogenic Ras Includes mTORC2. Mol. Cell 2019, 73, 830-844.e12. [CrossRef] [PubMed]

171. Ahearn, I.; Zhou, M.; Philips, M.R. Posttranslational Modifications of RAS Proteins. Cold Spring Harb. Perspect. Med. 2018, 8, a031484. [CrossRef]

172. Abdrabou, A.; Wang, Z. Post-Translational Modification and Subcellular Distribution of Rac1: An Update. Cells 2018, 7, 263. [CrossRef]

173. Khanna, A.; Lotfi, P.; Chavan, A.J.; Montano, N.M.; Bolourani, P.; Weeks, G.; Shen, Z.; Briggs, S.P.; Pots, H.; Van Haastert, P.J.; et al. The small GTPases Ras and Rap1 bind to and control TORC2 activity. Sci. Rep. 2016, 6, 25823. [CrossRef] [PubMed]

174. Sarbassov, D.D.; Guertin, D.A.; Ali, S.M.; Sabatini, D.M. Phosphorylation and regulation of Akt/PKB by the rictor-mTOR complex. Science 2005, 307, 1098-1101. [CrossRef] [PubMed] 
175. Chan, C.H.; Jo, U.; Kohrman, A.; Rezaeian, A.H.; Chou, P.C.; Logothetis, C.; Lin, H.K. Posttranslational regulation of Akt in human cancer. Cell Biosci. 2014, 4, 59. [CrossRef] [PubMed]

176. Liu, P.; Begley, M.; Michowski, W.; Inuzuka, H.; Ginzberg, M.; Gao, D.; Tsou, P.; Gan, W.; Papa, A.; Kim, B.M.; et al. Cellcycle-regulated activation of Akt kinase by phosphorylation at its carboxyl terminus. Nature 2014, 508, 541-545. [CrossRef] [PubMed]

177. Yang, W.L.; Wang, J.; Chan, C.H.; Lee, S.W.; Campos, A.D.; Lamothe, B.; Hur, L.; Grabiner, B.C.; Lin, X.; Darnay, B.G.; et al. The E3 ligase TRAF6 regulates Akt ubiquitination and activation. Science 2009, 325, 1134-1138. [CrossRef] [PubMed]

178. Chan, C.H.; Li, C.F.; Yang, W.L.; Gao, Y.; Lee, S.W.; Feng, Z.; Huang, H.Y.; Tsai, K.K.; Flores, L.G.; Shao, Y.; et al. The Skp2-SCF E3 ligase regulates Akt ubiquitination, glycolysis, herceptin sensitivity, and tumorigenesis. Cell 2012, 149, 1098-1111. [CrossRef] [PubMed]

179. Guo, J.; Dai, X.; Laurent, B.; Zheng, N.; Gan, W.; Zhang, J.; Guo, A.; Yuan, M.; Liu, P.; Asara, J.M.; et al. AKT methylation by SETDB1 promotes AKT kinase activity and oncogenic functions. Nat. Cell Biol. 2019, 21, 226-237. [CrossRef] [PubMed]

180. Wang, G.; Long, J.; Gao, Y.; Zhang, W.; Han, F.; Xu, C.; Sun, L.; Yang, S.C.; Lan, J.; Hou, Z.; et al. SETDB1-mediated methylation of Akt promotes its K63-linked ubiquitination and activation leading to tumorigenesis. Nat. Cell Biol. 2019, 21, 214-225. [CrossRef]

181. Guo, J.; Chakraborty, A.A.; Liu, P.; Gan, W.; Zheng, X.; Inuzuka, H.; Wang, B.; Zhang, J.; Zhang, L.; Yuan, M.; et al. pVHL suppresses kinase activity of Akt in a proline-hydroxylation-dependent manner. Science 2016, 353, 929-932. [CrossRef] [PubMed]

182. Hers, I.; Vincent, E.E.; Tavare, J.M. Akt signalling in health and disease. Cell Signal. 2011, 23, 1515-1527. [CrossRef] [PubMed]

183. Facchinetti, V.; Ouyang, W.; Wei, H.; Soto, N.; Lazorchak, A.; Gould, C.; Lowry, C.; Newton, A.C.; Mao, Y.; Miao, R.Q.; et al. The mammalian target of rapamycin complex 2 controls folding and stability of Akt and protein kinase C. EMBO J. 2008, 27, 1932-1943. [CrossRef] [PubMed]

184. Ikenoue, T.; Inoki, K.; Yang, Q.; Zhou, X.; Guan, K.L. Essential function of TORC2 in PKC and Akt turn motif phosphorylation, maturation and signalling. EMBO J. 2008, 27, 1919-1931. [CrossRef] [PubMed]

185. Wang, Y.; Wang, Y.; Zhang, H.; Gao, Y.; Huang, C.; Zhou, A.; Zhou, Y.; Li, Y. Sequential posttranslational modifications regulate PKC degradation. Mol. Biol. Cell 2016, 27, 410-420. [CrossRef] [PubMed]

186. Robles-Flores, M.; Melendez, L.; Garcia, W.; Mendoza-Hernandez, G.; Lam, T.T.; Castaneda-Patlan, C.; Gonzalez-Aguilar, H. Posttranslational modifications on protein kinase c isozymes. Effects of epinephrine and phorbol esters. Biochim. Biophys. Acta 2008, 1783, 695-712. [CrossRef]

187. Garcia-Martinez, J.M.; Alessi, D.R. mTOR complex 2 (mTORC2) controls hydrophobic motif phosphorylation and activation of serum- and glucocorticoid-induced protein kinase 1 (SGK1). Biochem. J. 2008, 416, 375-385. [CrossRef]

188. Di Cristofano, A. SGK1: The Dark Side of PI3K Signaling. Curr. Top. Dev. Biol. 2017, 123, 49-71.

189. Saunders, R.N.; Metcalfe, M.S.; Nicholson, M.L. Rapamycin in transplantation: A review of the evidence. Kidney Int. 2001, 59, 3-16. [CrossRef]

190. Zheng, Y.; Jiang, Y. mTOR Inhibitors at a Glance. Mol. Cell. Pharmacol. 2015, 7, 15-20.

191. Thoreen, C.C.; Sabatini, D.M. Rapamycin inhibits mTORC1, but not completely. Autophagy 2009, 5, 725-726. [CrossRef]

192. Chamberlain, C.E.; German, M.S.; Yang, K.; Wang, J.; VanBrocklin, H.; Regan, M.; Shokat, K.M.; Ducker, G.S.; Kim, G.E.; Hann, B.; et al. A Patient-derived Xenograft Model of Pancreatic Neuroendocrine Tumors Identifies Sapanisertib as a Possible New Treatment for Everolimus-resistant Tumors. Mol. Cancer Ther. 2018, 17, 2702-2709. [CrossRef] [PubMed]

193. Feldman, M.E.; Apsel, B.; Uotila, A.; Loewith, R.; Knight, Z.A.; Ruggero, D.; Shokat, K.M. Active-site inhibitors of mTOR target rapamycin-resistant outputs of mTORC1 and mTORC2. PLoS Biol. 2009, 7, e38. [CrossRef]

194. Jordan, N.J.; Dutkowski, C.M.; Barrow, D.; Mottram, H.J.; Hutcheson, I.R.; Nicholson, R.I.; Guichard, S.M.; Gee, J.M. Impact of dual mTORC1/2 mTOR kinase inhibitor AZD8055 on acquired endocrine resistance in breast cancer in vitro. Breast Cancer Res. 2014, 16, R12. [CrossRef] [PubMed]

195. Rodrik-Outmezguine, V.S.; Okaniwa, M.; Yao, Z.; Novotny, C.J.; McWhirter, C.; Banaji, A.; Won, H.; Wong, W.; Berger, M.; de Stanchina, E.; et al. Overcoming mTOR resistance mutations with a new-generation mTOR inhibitor. Nature 2016, 534, $272-276$. [CrossRef] [PubMed]

196. Fan, Q.; Aksoy, O.; Wong, R.A.; Ilkhanizadeh, S.; Novotny, C.J.; Gustafson, W.C.; Truong, A.Y.; Cayanan, G.; Simonds, E.F.; Haas-Kogan, D.; et al. A Kinase Inhibitor Targeted to mTORC1 Drives Regression in Glioblastoma. Cancer Cell 2017, 31, 424-435. [CrossRef] [PubMed]

197. Harrington, L.S.; Findlay, G.M.; Lamb, R.F. Restraining PI3K: mTOR signalling goes back to the membrane. Trends Biochem. Sci. 2005, 30, 35-42. [CrossRef] [PubMed]

198. Rodrik-Outmezguine, V.S.; Chandarlapaty, S.; Pagano, N.C.; Poulikakos, P.I.; Scaltriti, M.; Moskatel, E.; Baselga, J.; Guichard, S.; Rosen, N. mTOR kinase inhibition causes feedback-dependent biphasic regulation of AKT signaling. Cancer Discov. 2011, 1, 248-259. [CrossRef]

199. Formisano, L.; Napolitano, F.; Rosa, R.; D’Amato, V.; Servetto, A.; Marciano, R.; De Placido, P.; Bianco, C.; Bianco, R. Mechanisms of resistance to mTOR inhibitors. Crit. Rev. Oncol. Hematol. 2020, 147, 102886. [CrossRef] [PubMed]

200. Wise-Draper, T.M.; Moorthy, G.; Salkeni, M.A.; Karim, N.A.; Thomas, H.E.; Mercer, C.A.; Beg, M.S.; O'Gara, S.; Olowokure, O.; Fathallah, H.; et al. A Phase Ib Study of the Dual PI3K/mTOR Inhibitor Dactolisib (BEZ235) Combined with Everolimus in Patients with Advanced Solid Malignancies. Target. Oncol. 2017, 12, 323-332. [CrossRef] [PubMed] 
201. Fazio, N.; Buzzoni, R.; Baudin, E.; Antonuzzo, L.; Hubner, R.A.; Lahner, H.; WW, D.E.H.; Raderer, M.; Teule, A.; Capdevila, J.; et al. A Phase II Study of BEZ235 in Patients with Everolimus-resistant, Advanced Pancreatic Neuroendocrine Tumours. Anticancer Res. 2016, 36, 713-719. [PubMed]

202. Salazar, R.; Garcia-Carbonero, R.; Libutti, S.K.; Hendifar, A.E.; Custodio, A.; Guimbaud, R.; Lombard-Bohas, C.; Ricci, S.; Klumpen, H.J.; Capdevila, J.; et al. Phase II Study of BEZ235 versus Everolimus in Patients with Mammalian Target of Rapamycin Inhibitor-Naive Advanced Pancreatic Neuroendocrine Tumors. Oncologist 2018, 23, 766.e90. [CrossRef] [PubMed]

203. Yang, J.; Nie, J.; Ma, X.; Wei, Y.; Peng, Y.; Wei, X. Targeting PI3K in cancer: Mechanisms and advances in clinical trials. Mol. Cancer 2019, 18, 26. [CrossRef] [PubMed]

204. Ma, C.X.; Suman, V.; Goetz, M.P.; Northfelt, D.; Burkard, M.E.; Ademuyiwa, F.; Naughton, M.; Margenthaler, J.; Aft, R.; Gray, R.; et al. A Phase II Trial of Neoadjuvant MK-2206, an AKT Inhibitor, with Anastrozole in Clinical Stage II or III PIK3CAMutant ER-Positive and HER2-Negative Breast Cancer. Clin. Cancer Res. 2017, 23, 6823-6832. [CrossRef] [PubMed]

205. De Bono, J.S.; De Giorgi, U.; Rodrigues, D.N.; Massard, C.; Bracarda, S.; Font, A.; Arranz Arija, J.A.; Shih, K.C.; Radavoi, G.D.; Xu, N.; et al. Randomized Phase II Study Evaluating Akt Blockade with Ipatasertib, in Combination with Abiraterone, in Patients with Metastatic Prostate Cancer with and without PTEN Loss. Clin. Cancer Res. 2019, 25, 928-936. [CrossRef] [PubMed]

206. Banerji, U.; Dean, E.J.; Perez-Fidalgo, J.A.; Batist, G.; Bedard, P.L.; You, B.; Westin, S.N.; Kabos, P.; Garrett, M.D.; Tall, M.; et al. A Phase I Open-Label Study to Identify a Dosing Regimen of the Pan-AKT Inhibitor AZD5363 for Evaluation in Solid Tumors and in PIK3CA-Mutated Breast and Gynecologic Cancers. Clin. Cancer Res. 2018, 24, 2050-2059. [CrossRef] [PubMed]

207. Gonzalez, E.; McGraw, T.E. The Akt kinases: Isoform specificity in metabolism and cancer. Cell Cycle 2009, 8, 2502-2508. [CrossRef] [PubMed]

208. Nitulescu, G.M.; Margina, D.; Juzenas, P.; Peng, Q.; Olaru, O.T.; Saloustros, E.; Fenga, C.; Spandidos, D.; Libra, M.; Tsatsakis, A.M. Akt inhibitors in cancer treatment: The long journey from drug discovery to clinical use (Review). Int. J. Oncol. 2016, 48, 869-885. [CrossRef]

209. Anjum, R.; Blenis, J. The RSK family of kinases: Emerging roles in cellular signalling. Nat. Rev. Mol. Cell Biol. 2008, 9, 747-758. [CrossRef] [PubMed]

210. Lin, L.; White, S.A.; Hu, K. Role of p90RSK in Kidney and Other Diseases. Int. J. Mol. Sci. 2019, 20, 972. [CrossRef] [PubMed]

211. Weston, C.R.; Davis, R.J. The JNK signal transduction pathway. Curr. Opin. Cell Biol. 2007, 19, 142-149. [CrossRef] [PubMed]

212. Sabapathy, K. Role of the JNK pathway in human diseases. Prog. Mol. Biol. Trans. Sci. 2012, 106, 145-169.

213. Kumar, A.; Singh, U.K.; Kini, S.G.; Garg, V.; Agrawal, S.; Tomar, P.K.; Pathak, P.; Chaudhary, A.; Gupta, P.; Malik, A. JNK pathway signaling: A novel and smarter therapeutic targets for various biological diseases. Future Med. Chem. 2015, 7, 2065-2086. [CrossRef] [PubMed]

214. Arrouchi, H.; Lakhlili, W.; Ibrahimi, A. A review on PIM kinases in tumors. Bioinformation 2019, 15, 40-45. [CrossRef] [PubMed]

215. Zhang, X.; Song, M.; Kundu, J.K.; Lee, M.H.; Liu, Z.Z. PIM Kinase as an Executional Target in Cancer. J. Cancer Prev. 2018, 23, 109-116. [CrossRef] [PubMed]

216. Keane, N.A.; Reidy, M.; Natoni, A.; Raab, M.S.; O'Dwyer, M. Targeting the Pim kinases in multiple myeloma. Blood Cancer J. 2015, 5, e325. [CrossRef] [PubMed]

217. Chae, S.W.; Sohn, J.H.; Kim, D.H.; Choi, Y.J.; Park, Y.L.; Kim, K.; Cho, Y.H.; Pyo, J.S.; Kim, J.H. Overexpressions of Cyclin B1, cdc2, p16 and p53 in human breast cancer: The clinicopathologic correlations and prognostic implications. Yonsei Med. J. 2011, 52, 445-453. [CrossRef] [PubMed]

218. Prescott, J.A.; Cook, S.J. Targeting IKKbeta in Cancer: Challenges and Opportunities for the Therapeutic Utilisation of IKKbeta Inhibitors. Cells 2018, 7, 115. [CrossRef] [PubMed]

219. Steinberg, G.R.; Carling, D. AMP-activated protein kinase: The current landscape for drug development. Nat. Rev. Drug Discov. 2019, 18, 527-551. [CrossRef] [PubMed]

220. Ma, S.; Meng, Z.; Chen, R.; Guan, K.L. The Hippo Pathway: Biology and Pathophysiology. Annu. Rev. Biochem. 2019, 88, 577-604. [CrossRef] [PubMed]

221. Liu, L.; Yan, L.; Liao, N.; Wu, W.Q.; Shi, J.L. A Review of ULK1-Mediated Autophagy in Drug Resistance of Cancer. Cancers 2020, 12, 352. [CrossRef]

222. Cohen, P.; Goedert, M. GSK3 inhibitors: Development and therapeutic potential. Nat. Rev. Drug Discov. 2004, 3, 479-487. [CrossRef] [PubMed]

223. Hwang, D.Y.; Eom, J.I.; Jang, J.E.; Jeung, H.K.; Chung, H.; Kim, J.S.; Cheong, J.W.; Min, Y.H. ULK1 inhibition as a targeted therapeutic strategy for FLT3-ITD-mutated acute myeloid leukemia. J. Exp. Clin. Cancer Res. 2020, 39, 85. [CrossRef] [PubMed]

224. Martin, K.R.; Celano, S.L.; Solitro, A.R.; Gunaydin, H.; Scott, M.; O’Hagan, R.C.; Shumway, S.D.; Fuller, P.; MacKeigan, J.P. A Potent and Selective ULK1 Inhibitor Suppresses Autophagy and Sensitizes Cancer Cells to Nutrient Stress. IScience 2018, 8, 74-84. [CrossRef] [PubMed]

225. Shimizu, K.; Nihira, N.T.; Inuzuka, H.; Wei, W. Physiological functions of FBW7 in cancer and metabolism. Cell Signal. 2018, 46, 15-22. [CrossRef] [PubMed]

226. Liu, J.; Zhang, C.; Hu, W.; Feng, Z. Parkinson's disease-associated protein Parkin: An unusual player in cancer. Cancer Commun. (Lond.) 2018, 38, 40. [CrossRef] [PubMed]

227. Fujiwara, M.; Marusawa, H.; Wang, H.Q.; Iwai, A.; Ikeuchi, K.; Imai, Y.; Kataoka, A.; Nukina, N.; Takahashi, R.; Chiba, T. Parkin as a tumor suppressor gene for hepatocellular carcinoma. Oncogene 2008, 27, 6002-6011. [CrossRef] [PubMed] 
228. Cai, Z.; Moten, A.; Peng, D.; Hsu, C.C.; Pan, B.S.; Manne, R.; Li, H.Y.; Lin, H.K. The Skp2 Pathway: A Critical Target for Cancer Therapy. Semin. Cancer Biol. 2020, 67, 16-33. [CrossRef]

229. Chan, C.H.; Morrow, J.K.; Li, C.F.; Gao, Y.; Jin, G.; Moten, A.; Stagg, L.J.; Ladbury, J.E.; Cai, Z.; Xu, D.; et al. Pharmacological inactivation of Skp2 SCF ubiquitin ligase restricts cancer stem cell traits and cancer progression. Cell 2013, 154, 556-568. [CrossRef] [PubMed]

230. Chen, Q.; Xie, W.; Kuhn, D.J.; Voorhees, P.M.; Lopez-Girona, A.; Mendy, D.; Corral, L.G.; Krenitsky, V.P.; Xu, W.; Moutouh-de Parseval, L.; et al. Targeting the p27 E3 ligase SCF(Skp2) results in p27- and Skp2-mediated cell-cycle arrest and activation of autophagy. Blood 2008, 111, 4690-4699. [CrossRef]

231. Wu, L.; Grigoryan, A.V.; Li, Y.; Hao, B.; Pagano, M.; Cardozo, T.J. Specific small molecule inhibitors of Skp2-mediated p27 degradation. Chem. Biol. 2012, 19, 1515-1524. [CrossRef]

232. Okamoto, T.; Imaizumi, K.; Kaneko, M. The Role of Tissue-Specific Ubiquitin Ligases, RNF183, RNF186, RNF182 and RNF152, in Disease and Biological Function. Int. J. Mol. Sci. 2020, 21, 3921. [CrossRef] [PubMed]

233. Lalani, A.I.; Zhu, S.; Gokhale, S.; Jin, J.; Xie, P. TRAF molecules in inflammation and inflammatory diseases. Curr. Pharmacol. Rep. 2018, 4, 64-90. [CrossRef]

234. Zhu, S.; Jin, J.; Gokhale, S.; Lu, A.M.; Shan, H.; Feng, J.; Xie, P. Genetic Alterations of TRAF Proteins in Human Cancers. Front. Immunol. 2018, 9, 2111. [CrossRef] [PubMed]

235. Mevissen, T.E.; Hospenthal, M.K.; Geurink, P.P.; Elliott, P.R.; Akutsu, M.; Arnaudo, N.; Ekkebus, R.; Kulathu, Y.; Wauer, T.; El Oualid, F.; et al. OTU deubiquitinases reveal mechanisms of linkage specificity and enable ubiquitin chain restriction analysis. Cell 2013, 154, 169-184. [CrossRef] [PubMed]

236. Hu, H.; Wang, H.; Xiao, Y.; Jin, J.; Chang, J.H.; Zou, Q.; Xie, X.; Cheng, X.; Sun, S.C. Otud7b facilitates T cell activation and inflammatory responses by regulating Zap70 ubiquitination. J. Exp. Med. 2016, 213, 399-414. [CrossRef] [PubMed]

237. Hu, H.; Brittain, G.C.; Chang, J.H.; Puebla-Osorio, N.; Jin, J.; Zal, A.; Xiao, Y.; Cheng, X.; Chang, M.; Fu, Y.X.; et al. OTUD7B controls non-canonical NF-kappaB activation through deubiquitination of TRAF3. Nature 2013, 494, 371-374. [CrossRef] [PubMed]

238. Pareja, F.; Ferraro, D.A.; Rubin, C.; Cohen-Dvashi, H.; Zhang, F.; Aulmann, S.; Ben-Chetrit, N.; Pines, G.; Navon, R.; Crosetto, N.; et al. Deubiquitination of EGFR by Cezanne-1 contributes to cancer progression. Oncogene 2012, 31, $4599-4608$. [CrossRef] [PubMed]

239. Lin, D.D.; Shen, Y.; Qiao, S.; Liu, W.W.; Zheng, L.; Wang, Y.N.; Cui, N.; Wang, Y.F.; Zhao, S.; Shi, J.H. Upregulation of OTUD7B (Cezanne) Promotes Tumor Progression via AKT/VEGF Pathway in Lung Squamous Carcinoma and Adenocarcinoma. Front. Oncol. 2019, 9, 862. [CrossRef] [PubMed]

240. Setsuie, R.; Wada, K. The functions of UCH-L1 and its relation to neurodegenerative diseases. Neurochem. Int. 2007, 51, 105-111. [CrossRef]

241. Wu, H.Q.; Baker, D.; Ovaa, H. Small molecules that target the ubiquitin system. Biochem. Soc. Trans. 2020, 48, 479-497. [CrossRef] [PubMed]

242. Ottis, P.; Crews, C.M. Proteolysis-Targeting Chimeras: Induced Protein Degradation as a Therapeutic Strategy. ACS Chem. Biol. 2017, 12, 892-898. [CrossRef] [PubMed]

243. Schapira, M.; Calabrese, M.F.; Bullock, A.N.; Crews, C.M. Targeted protein degradation: Expanding the toolbox. Nat. Rev. Drug Discov. 2019, 18, 949-963. [CrossRef] [PubMed]

244. Mullard, A. Arvinas's PROTACs pass first safety and PK analysis. Nat. Rev. Drug Discov. 2019, 18, 895. [CrossRef] [PubMed]

245. Xu, K.; Liu, P.; Wei, W. mTOR signaling in tumorigenesis. Biochim. Biophys. Acta 2014, 1846, 638-654. [CrossRef] [PubMed] 